\title{
N-acetyl-L-tryptophan Delays Disease Onset and Extends Survival in an Amyotrophic Lateral Sclerosis Transgenic Mouse Model
}

Wei Li ${ }^{\text {a }}$, Anastasios Fotinos ${ }^{\mathrm{a}}$, Qiaofeng Wu ${ }^{\mathrm{a}}$, Yanchun Chen ${ }^{\mathrm{a}}$, Yongjin Zhu ${ }^{\mathrm{a}}$, Sergei Baranov ${ }^{\mathrm{a}, \mathrm{b}}$,

Yanyang Tu ${ }^{\text {a }}$, Edward W. Zhou ${ }^{\text {a }}$, Bharati Sinha ${ }^{\text {a }}$, Bruce S. Kristal ${ }^{\text {a,b }}$, and Xin Wang ${ }^{\text {a,* }}$

${ }^{a}$ Department of Neurosurgery and ${ }^{b}$ Department of Surgery, Brigham and Women's Hospital, Harvard

Medical School, Boston, Massachusetts 02115, USA

Running Title: Neuroprotection of L-NAT in $\mathrm{mSOD} 1^{\text {G93A }}$ ALS mice

To whom correspondence should be addressed: Xin Wang, Ph.D., Department of Neurosurgery, Brigham and Women's Hospital/Harvard Medical School, 221 Longwood Ave. Boston, MA 02115, USA, Telephone number: 617-732-4186, Email: xwang@rics.bwh.harvard.edu

Key words: N-acetyl-L-tryptophan; Amyotrophic Lateral Sclerosis; $m S O D 1^{G 93 A}$ mice; Neuroprotection; Mitochondrial Death Pathway; Inflammation; Neurokinin 1 receptor

Background: Whether L-NAT, a cytochrome c release inhibitor and an antagonist of NK-1R, provides protection in ALS is not known.

Results: L-NAT delays disease onset and mortality in mSOD ${ }^{\mathrm{G} 93 \mathrm{~A}}$ ALS mice by inhibiting mitochondrial cell death pathways, inflammation, and NK-1R downregulation.

Conclusion: L-NAT offers protection in a mouse model of ALS.

Significance: Data suggest the potential of L-NAT as a novel therapeutic strategy for ALS and provide insight into its action mechanisms.

\section{ABSTRACT}

Amyotrophic lateral sclerosis (ALS) is a neurodegenerative disease characterized by progressive motor neuron loss, while inflammation has been implicated in its pathogenesis. Both inhibitors of cytochrome c release and antagonists of the neurokinin 1 receptor (NK-1R) have been reported to provide neuroprotection in ALS and/or other neurodegenerative diseases by us and other researchers. However, whether N-acetyl-L-tryptophan (L-NAT), an inhibitor of cytochrome c release and an antagonist of NK$1 \mathrm{R}$, provides neuroprotection in ALS remains unknown. Here we demonstrate that the administration of L-NAT delayed disease onset, extended survival, and ameliorated deteriorations in motor performance in mSOD1 ${ }^{\mathrm{G} 93 \mathrm{~A}}$ ALS transgenic mice. Our data showed that L-NAT reached spinal cord, skeletal muscle, and brain. In addition, we demonstrate that L-NAT reduced the release of cytochrome c/smac/AIF, increased Bcl-xL levels, and inhibited the activation of caspase-3. L-NAT also ameliorated motor neuron loss and gross atrophy, and suppressed inflammation, as shown by decreased GFAP and Iba1 levels. Furthermore, we found gradually reduced neurokinin 1 receptor (NK-1R) levels in the spinal cords of mSOD1 ${ }^{\mathrm{G} 93 \mathrm{~A}}$ mice, while L-NAT treatment restored NK-1R levels. We propose the use of L-NAT as a potential therapeutic invention against ALS.

\section{Introduction}

Amyotrophic lateral sclerosis (ALS) is a devastating chronic neurodegenerative disease affecting central and peripheral motor neurons, leading to skeletal muscle weakness, followed by paralysis and 
eventual death due to respiratory failure within 3-5 years. Although the mechanisms underlying the pathogenesis of ALS have not been thoroughly elucidated, multiple pathological events have been associated with ALS. Mitochondrial dysfunction, apoptotic pathological features, neuroinflammation are among the pathological events identified in ALS.

Apoptotic cell death plays an important role in ALS pathogenesis in both human patients and mouse models of ALS. With specific types of stress or damage, pro-apoptotic molecules including cytochrome c, smac, and AIF located within mitochondria are released into the cytoplasm, leading to activation of the downstream molecule caspase-3, which results in apoptotic neuronal death.

Chronic inflammation plays an important role in the pathogenesis of ALS (McCombe \& Henderson, 2011). Emerging evidence supports the involvement of neighboring non-motor-neuron cell types including astrocytes, microglia, and others in the process of ALS-related pathological development. Increased expression of glial fibrillary acidic protein (GFAP) indicates astroglial activation and gliosis during neurodegeneration (Brahmachari et al., 2006), while Iba1, an actin-binding protein, is an effective microglial marker. Astrogliosis and microgliosis are notable hallmarks of ALS disease and are present not only in ALS mice but also in post-mortem spinal cord tissue from familial and sporadic ALS patients (Schiffer et al., 1996; Guan et al., 2007; Pandya et al., 2013; Zhang et al., 2013). Stage-dependent progression of astrogliosis (indicated by increased GFAP expression) and microglial activation (marked by increased expression of Iba1) in mSOD1 ALS mice have been reported by us and other researchers (Guan et al., 2007; Yu et al., 2013; Cui et al., 2014) and have been used as targets for screening potential therapeutic agents for ALS (Pandya et al., 2013). Astrocytes carrying ALS-causing genes, especially mutated SOD1, as the non-cell autonomous components in ALS pathogenesis may play a critical role in stimulating damage and degeneration of neighboring motor neurons (Li et al., 2013; Pandya et al., 2013).

Our previous study screened the 1040-compound library for inhibition of release of cytochrome c and found that $\mathrm{N}$-acetyl-tryptophan (NAT) ranked $13^{\text {th }}$ in the purified mitochondria system and inhibited mutant-huntingtin-induced ST14A striatal cell death (Wang et al., 2008). N-acetyl-L-tryptophan (L-NAT), an antagonist of the neurokinin 1 receptor (NK-1R) known to disrupt the binding of Substance $\mathrm{P}$ (SP) to NK-1R, significantly improved motor and cognitive outcomes and inhibited dyskinesia in a hemiparkinsonian rat model (Thornton et al., 2014), as well as provided neuroprotection in models of Parkinson's disease (Thornton \& Vink, 2012) and reduced brain edema and axonal injury in experimental models of traumatic brain injury (Vink et al., 2004; Donkin et al., 2009; Donkin et al., 2010) and stroke (Turner et al., 2005). However, little is known about the molecular mechanisms underlying L-NAT's neuroprotection. Most important, whether L-NAT provides neuroprotection in ALS remains mysterious.

Here we evaluate the neuroprotective ability of L-NAT in mSOD1 ${ }^{\text {G93A }}$ ALS mice. We demonstrate that L-NAT delayed disease onset, extended survival, reduced apoptosis, ameliorated motor neuron loss, and suppressed inflammation; thus L-NAT may be a novel effective therapeutic agent for ALS.

\section{Materials and methods}

Drugs

L-NAT was purchased from Sigma-Aldrich or Microsource Discovery Systems Inc. Cyclosporin A (CsA) was purchased from Sigma-Aldrich.

\section{Mice and treatment regimen}

The $\mathrm{mSOD} 1^{\mathrm{G} 93 \mathrm{~A}}$ transgenic mice suffer from a progressive motor weakness and paralysis resembling those in the human ALS. The $\mathrm{mSOD} 1^{\mathrm{G} 93 \mathrm{~A}}$ transgenic mice have become a widely used animal model for preclinical screening to discover the potential curative therapies to carry forward to clinical trials. Male transgenic mice expressing human mutant superoxide dismutase SOD1 ${ }^{\mathrm{G} 93 \mathrm{~A}}$ in the B6SJL genetic background were crossbred with background-matched wild-type (WT) females (Jackson Laboratories, Bar Harbor, ME, USA). The F1 progeny were genotyped and used in subsequent studies. All experiments were conducted in accordance with protocols approved by the Harvard Medical School 
Animal Care Committee (Wang et al., 2007; Zhang et al., 2013). mSOD1 ${ }^{\text {G93A }}$ mice received daily intraperitoneal (IP) injections of L-NAT starting at six weeks of age. The drug regimen consisted of 15, 30, and $60 \mathrm{mg} \mathrm{kg}$ /day L-NAT, while ALS animals and control WT mice received the saline vehicle on the same schedule as the saline-treated groups. The three groups receiving L-NAT included $n=30$ (15 $\mathrm{mg} / \mathrm{kg}), 25(30 \mathrm{mg} / \mathrm{kg})$, and $24(60 \mathrm{mg} / \mathrm{kg})$ animals, respectively. ALS $(n=31)$ and WT $(n=30)$ mice received saline vehicle. For all experiments, each group contained equal (or nearly equal) numbers of males and females.

\section{Evaluation of motor function, onset, and survival}

Motor strength and coordination were evaluated weekly using a rotarod (Columbus Instruments, Columbus, OH, USA) as previously described (Li et al., 2000b; Wang et al., 2007). Mice were given two days to become acquainted with the apparatus. Mice were evaluated at both 15 and $5 \mathrm{rpm}$ rotarod speeds. Disease onset was defined as the first day that the mouse failed to complete $7 \mathrm{~min}$ at $15 \mathrm{rpm}$. Mortality was defined as the age at death or when the mouse was unable to right itself within 30 seconds. Body weight was monitored weekly. Fresh L-NAT was prepared and intraperitoneally injected daily.

\section{Neurological scoring system}

A neurological score was employed to assess the pathological progress of mSOD1 ${ }^{\mathrm{G} 93 \mathrm{~A}}$ mice (Gill et al., 2009; Kaneb et al., 2011). Scoring on a scale of 0-4 was conducted daily for mSOD ${ }^{\mathrm{G} 93 \mathrm{~A}}$ mice from 90 days of age using the following criteria. Score 0: Full extension of hind legs away from lateral midline when mouse is suspended by its tail, and mouse can hold this for two seconds, suspended two to three times. Score 1: Collapse or partial collapse of leg extension towards lateral midline (weakness) or trembling of hind legs during tail suspension. Score 2: Toes curl under at least twice during walking of 12 inches, or any part of foot is dragging along cage bottom/table; when the mice are unable to run for longer than $1 \mathrm{~min}$ at $15 \mathrm{rpm}$. Score 3: Rigid paralysis or minimal joint movement, foot not being used for generating forward motion. Score 3.5: paralysis in both hind legs. Score 4: Mouse cannot right itself within 30 seconds after being placed on either side; or ascend to the forelimbs; or death.

\section{Motor neuron counting and gross atrophy evaluation}

mSOD1 ${ }^{\mathrm{G} 93 \mathrm{~A}}$ mice received daily IP injections of L-NAT starting at six weeks of age, while ALS mice and control WT mice received the saline vehicle on the same schedule as the saline-treated groups. At 17-18 weeks of age, mice were anaesthetized with pentobarbital solution, perfused with 4\% paraformaldehyde (PFA) by transcardiac injection, and spinal cords were removed. Tissue blocks were post-fixed with $4 \%$ PFA solution overnight, followed with $30 \%$ sucrose solution for $24 \mathrm{~h}$. Selected serial lumbar spinal cords were sectioned at $18 \mu \mathrm{m}$ by a cryostat and stored at $-80{ }^{\circ} \mathrm{C}$. Continuous 10 sections per mouse in each group were subjected to Nissl staining. Stained motor neurons with clearly visible nucleoli were counted in the ventral horns of all sections spanning the lumbar regions at the L2-3 level by a blinded and trained observer. The numbers reported for each group of mice were average motor neurons per section unilaterally (including right and left ventral horns) among 10 continuous sections from each of five animals. The area of total spinal cord section, grey and white matter were measured in the same Nissl stained sections using Image $\mathbf{J}$ software (National Institutes of Health, Bethesda, MD, USA). An average area per section was calculated for mice in each group.

\section{Western blot}

$\mathrm{mSOD} 1^{\mathrm{G} 93 \mathrm{~A}}$ mice received daily IP injections of saline or 15 or $30 \mathrm{mg} / \mathrm{kg}$ L-NAT starting at 6 weeks of age. Spinal cords were removed at indicated age of 10,13-14, and 17-18 weeks and extracted in lysis buffer [20 mM Tris, $\mathrm{pH} 8.0 / 137 \mathrm{mM} \mathrm{NaCl} / 10 \%$ glycerol/1\% Nonidet P-40/2 mM EDTA with $5 \mathrm{mM}$ $\mathrm{Na} 2 \mathrm{VO} 4$, protease inhibitor mixture (Roche Molecular Biochemicals)/0.2 $\mathrm{mM}$ phenylmethylsulfonyl fluoride] on ice, centrifuged at $19,720 \mathrm{x} \mathrm{g}$ for $10 \mathrm{~min}$ at $4{ }^{\circ} \mathrm{C}$, and the proteins were separated by SDSPAGE, transferred to polyvinylidene fluoride membranes, and incubated with the following antibodies: 
anti-Bcl-xL antibody (1:1000; Santa Cruz Biotechnology); anti-caspase-3 antibody (1:1000; Cell Signaling Technology); anti-GFAP antibody (1:1000; Santa Cruz Biotechnology); anit-iba1 antibody (1:1000; Wako Pure Chemical Industries, Ltd. Japan); anit-NK1 antibody (1:1000; Novus Biologicals Inc.); and anti- $\beta$-actin antibody (1:5000; Sigma-Aldrich). The secondary antibodies and ECL reagents were purchased from Amersham Pharmacia Biotech.

\section{Immunohistochemistry}

Animals were anesthetized deeply and then perfused intracardially with $4 \%$ paraformaldehyde in $0.01 \mathrm{M}$ PBS (pH 7.4). Spinal cords of mice were removed, post-fixed in 4\% paraformaldehyde overnight at $4{ }^{\circ} \mathrm{C}$, and then transferred to $30 \%$ sucrose for cryopreservation. Spinal cords were cut and embedded in cryomolds (Fisher Scientific) with Tissue-Tek Optimal Cutting Temperature Compound (O.C.T) (Sakura) and further sectioned coronally on a cryostat at $18-\mu \mathrm{m}$ intervals and stored at $-80^{\circ} \mathrm{C}$.

Frozen sections were fixed with $4 \%$ paraformaldehyde for 15-20 min, penetrated with $1 \%$ Triton $\mathrm{X}-100$ for $10 \mathrm{~min}$, and blocked with $5 \%$ normal goat serum for 1 hour. The following primary antibodies were applied overnight at $4{ }^{\circ} \mathrm{C}$ at the indicated dilutions in $2 \%$ goat serum in PBS with $0.1 \%$ Triton X-100: rabbit anti-NK-1R (1:200, Acris Antibodies GmbH, Germany), rabbit anti-NK-1R or mouse anti-NK-1R (1:100, Novus Biologicals, Inc.), mouse anti-NeuN (1:200, Abcam), rabbit anti-Iba1 (1:200, Wako Pure Chemical Industries, Ltd. Japan), rabbit anti-GFAP (1:200, DAKO, Denmark), and mouse anti-GFAP (1:300, Cell Signaling Technology). Sections were washed in PBS with 0.1\% Tween-20 and reacted with secondary antibodies: goat anti-rabbit $\operatorname{IgG}(\mathrm{H}+\mathrm{L})$ conjugated to FITC (1:200, Vector laboratories Inc. Canada), donkey anti-rabbit IgG (H+L) conjugated to Alexa Flour 594 (1:200, Jackson ImmunoResearch Laboratories, Inc.), and donkey anti-mouse conjugated to Fluorescein (1:150, Vector laboratories Inc. Canada) in a dark humidity chamber for 1 hour at room temperature. After washing in PBS with 0.1\% Tween-20, sections were immediately examined under a Nikon Diaphot 300 Inverted Fluorescence Microscope.

\section{Subcellular fractionation}

Spinal cords of treated $\mathrm{mSOD} 1^{\mathrm{G} 93 \mathrm{~A}}$ mice were extracted as described above, and cytosolic and mitochondrial fractionation were performed as described (Wang et al., 2007; Zhang et al., 2013). The samples were homogenized in a Dounce homogenizer by 10-15 strokes on ice in a homogenization buffer (10 mM HEPES, pH 7.4, $250 \mathrm{mM}$ sucrose, $10 \mathrm{mM} \mathrm{KCl,} 1.5 \mathrm{mM} \mathrm{MgCl}_{2}, 1 \mathrm{mM}$ EDTA, $1 \mathrm{mM}$ EGTA, 1 $\mathrm{mM}$ DTT plus protease inhibitor cocktail [Roche]), followed by $700 \times \mathrm{g}$ centrifugation for $5 \mathrm{~min}$ at $4^{\circ} \mathrm{C}$; the supernatant was centrifuged at $15,000 \times \mathrm{g}$ for $25 \mathrm{~min}$ at $4^{\circ} \mathrm{C}$ and used as the cytosolic component. Pellets were lysed with RIPA buffer for 10 min on ice, and supernatants were added to the sample buffer to obtain the membrane fraction containing mitochondria. Cytochrome c (1:1000; Clonetech)/smac (1:800; Abcam)/AIF (1:800; sigma-aldrich) were analyzed by western blot.

\section{Measurement of mitochondrial swelling in isolated mitochondria}

Liver mitochondria were isolated from male Fischer 344 x Brown Norway F rats 4-6 months old by differential centrifugation using sucrose-based isolation buffer as described previously (Baranov et al., 2008). Swelling assay was run in $240 \mathrm{mM}$ sucrose, $10 \mathrm{mM}$ Hepes, $\mathrm{pH} 7.4,1 \mathrm{mM} \mathrm{K} \mathrm{HPO}_{4}, 5 \mathrm{mM}$ succinate, and $30 \mu \mathrm{M} \mathrm{CaCl}_{2}$ for $60 \mathrm{~min}$. L-NAT was used at $10 \mu \mathrm{M}$. Final mitochondrial concentration was $0.5 \mathrm{mg}$ protein/ml. Swelling was monitored by following the changes in absorbance at $540 \mathrm{~nm}$ using a SpectraMax 250 microplate reader (Molecular Devices).

\section{Liquid chromatography/mass spectrometry (LC/MS) assay}

mSOD1 ${ }^{\mathrm{G} 93 \mathrm{~A}}$ mice received daily IP injections of L-NAT or saline starting at six weeks of age. Spinal cord, brain, and muscle tissues were harvested at the end-stage (17-18 weeks old age) after chronic treatment and 1 hour after the final IP injection. Homogenate was obtained using a Dounce homogenizer. 
$\mathrm{ddH}_{2} \mathrm{O}$ was added to reach a concentration of $200 \mathrm{mg}$ (tissue weight) $/ \mathrm{ml}$. Four tissue volumes of cold methanol was added to the tissue homogenomate followed by centrifugation at $14,000 \mathrm{rpm}, 4^{\circ} \mathrm{C}$ for 15 min to collect the supernatant, which was subjected to LC/MS analysis conducted in the FAS Center for Systems Biology, Harvard University. The concentration of L-NAT in the samples was quantified against a standard curve.

\section{Statistical analysis}

Densitometric quantification was performed with the Quantity One Program (Bio-Rad). Statistical significance was evaluated by One-Way ANOVA and by repeated measures t-test in analysis of body weight and neuroscoring, $p$ values $<0.05$ were considered significant and are indicated $(*)$, and ** indicates $p$ values $<0.01$, *** indicates $p$ values $<0.001$. Cumulative probability of onset and survival data was analyzed using the GraphPad Prism 5.0 program.

\section{Results}

$N$-acetyl-L-tryptophan delays disease onset and extends survival in mSOD1 ${ }^{G 93 A}$ ALS mice

L-NAT offered neuroprotection and improved motor and cognitive outcomes in rat models of chronic Parkinson's disease (Thornton \& Vink, 2012; Thornton et al., 2014). To determine whether LNAT also offers neuroprotection in another chronic neurodegenerative disease ALS, we evaluated the effects of naturally occurring L-NAT on $\mathrm{mSOD} 1^{\mathrm{G} 93 \mathrm{~A}}$ transgenic mice. $\mathrm{mSOD} 1^{\mathrm{G} 93 \mathrm{~A}}$ mice, which develop a syndrome whose symptoms and histopathology resemble those of ALS, have been extensively used by us and others as an animal model of ALS (Gurney et al., 1994; Guan et al., 2007; Wang et al., 2007; Chen et al., 2012a; Chen et al., 2012b; Zhang et al., 2013; Zhou et al., 2013). ALS mice were intraperitoneally injected daily with L-NAT beginning at six weeks of age. To evaluate motor strength and coordination, mice were evaluated weekly on a rotarod. Kaplan-Meier curves of disease onset (Fig. 1A) and survival (Fig. 1B) as well as plots of rotarod performance were constructed. Average latency to fall during rotarod performance at $15 \mathrm{rpm}$ (a marker of early deficits) and $5 \mathrm{rpm}$ (a more sensitive test for advanced disease) were recorded. We also monitored body weight weekly; 15, 30, and $60 \mathrm{mg} / \mathrm{kg}$ of L-NAT did not affect the degree of weight loss in ALS mice suggests that the protection of L-NAT are not associated with body weight loss (Fig. 1D). Neurological scoring was developed to assess disease onset, progression, and end point in ALS mice (Gill et al., 2009; Kaneb et al., 2011). Neuroscoring in Fig. 1E indicates daily symptoms in $\mathrm{mSOD} 1^{\mathrm{G} 93 \mathrm{~A}}$ mice. These mice had low neurological scores before symptom onset and increased score with symptom progression, while L-NAT-treated $\mathrm{mSOD}{ }^{\mathrm{G} 93 \mathrm{~A}}$ mice scored lower than saline-treated mSOD1 ${ }^{\mathrm{G} 93 \mathrm{~A}}$ mice and WT mice show no impairment in motor function (Fig. 1E).

Onset of impaired motor performance in $\mathrm{mSOD} 1^{\mathrm{G} 93 \mathrm{~A}}$ ALS mice given 15 and $30 \mathrm{mg} / \mathrm{kg}$ L-NAT was delayed to $111.3 \pm 1.8$ and $111.3 \pm 3.0$ days of age, as compared to $100.3 \pm 2.1$ days in saline-treated mSOD ${ }^{\mathrm{G} 93 \mathrm{~A}}$ mice (Fig. 1A, C). In other words, L-NAT delayed disease onset by $11.0 \%$ and $11.0 \%$ when mSOD1 ${ }^{\mathrm{G} 93 \mathrm{~A}}$ mice were administered 15 and $30 \mathrm{mgkg}$, respectively (Fig. $1 \mathrm{~A}, \mathrm{C}, * * p<0.01, * * * p<0.001$ ). The regimen of 15 and $30 \mathrm{mg} / \mathrm{kg}$ L-NAT extended survival to $130.3 \pm 2.4$ and $132.8 \pm 2.6$ days respectively from $120.6 \pm 2.4$ days in saline-treated $\mathrm{mSOD} 1^{\mathrm{G} 93 \mathrm{~A}}$ mice (Fig. $1 \mathrm{~B}, \mathrm{C}$ ), delaying mortality by $8.0 \%$ and $10.1 \%$, respectively in the manner of dose-dependent (Fig. 1B, C, $* * p<0.01$ ). However, compared with saline-treated $\mathrm{mSOD} 1^{\mathrm{G} 93 \mathrm{~A}}$ mice, mortality occurred earlier in the group treated with the high dose $(60 \mathrm{mg} / \mathrm{kg} \mathrm{L}-\mathrm{NAT})$, and survival decreased to $116.0 \pm 4.1$ days (data not shown). The accelerated disease progression at the highest dose might be due to the accumulated toxicity of L-NAT in a long-term trial.

In summary, data on cumulative probability of onset, survival, and rotarod performance, as well as neurological score clearly demonstrate that administration of 15 and $30 \mathrm{mg} / \mathrm{kg}$ L-NAT resulted in significant protective effects, delaying disease onset and extending the lifespan of $\mathrm{mSOD} 1^{\mathrm{G} 93 \mathrm{~A}}$ mice.

\section{LC-MS for L-NAT determination in $\mathrm{mSOD}^{\mathrm{G} 93 A}$ ALS mice}


LC/MS measurements were employed to investigate whether IP injection of L-NAT in ALS mice can penetrate the blood-brain barrier (BBB) to reach the central neuron system (CNS). The data showed that IP injection of L-NAT reaches a level of $14.5 \mathrm{ng} / \mathrm{mg}$ in the brain tissue of $\mathrm{mSOD} 1{ }^{\mathrm{G} 93 \mathrm{~A}}$ mice receiving chronic treatment of $60 \mathrm{mg} / \mathrm{kg}$ L-NAT (Fig. 2A), whereas it was undetectable in saline-treated controls (data not shown). The determination of the concentration of L-NAT in the brain tissue of ALS mice confirms that the reliability of LC/MS assay.

ALS is a neurodegenerative disorder that causes progressive motor neuron degeneration in spinal cord, and skeletal muscle atrophy (Pandya et al., 2012; Pandya et al., 2013), we next sought to determine whether L-NAT can reach the tissues most strongly affected in ALS, specifically including the spinal cord and peripheral skeletal muscle (Gastrocnemius in the hindlimb). Our data indicate that delivery of L-NAT at the effective dose of $15 \mathrm{mg} / \mathrm{kg}$ by IP injection indeed reaches the brain, spinal cord and muscles of mice by the robust counts $(812,835$, and $949 \mathrm{ng} / \mathrm{ml}$, respectively) compared with the baseline count in blank control (Fig. 2B). Taken together, our findings regarding the distribution of L-NAT in brain, spinal cord, and muscle of mSOD1 ${ }^{\mathrm{G} 93 \mathrm{~A}}$ ALS mice provide direct evidence that L-NAT is absorbed and penetrates the $\mathrm{BBB}$ to reach the CNS tissues as well as skeletal muscle, suggesting that L-NAT can reach critical regions to influence the in vivo microenvironment of motor neurons and glial cells.

\section{L-NAT rescues motor neurons in $\mathrm{mSOD} 1^{\text {G93A }}$ ALS mice}

We then investigated L-NAT's ability to inhibit motor neuron death, since the hallmark of ALS pathology is the degeneration of motor neurons in spinal cord. Mouse lumbar sections at 17-18 weeks of age were evaluated by Nissl staining. Compared with WT mice, vehicle-treated mSOD1 ${ }^{\text {G93A }}$ ALS mice showed a massive loss of motor neurons in the ventral horn of sections. Furthermore, we counted the neurons in the ventral horns of spinal cords at the lumbar level in L-NAT-treated mSOD1 ${ }^{\text {G93A }}$ ALS mice. Indeed, L-NAT reduced motor neuron loss compared with saline-treated ALS mice tested at this age (wild-type mice, $10.5 \pm 1.3$; saline-treated ALS mice, $3.1 \pm 1.2$; L-NAT-treated ALS mice, $8.2 \pm 1.3$; Fig. $3 \mathrm{~A}-\mathrm{F})$. Moreover, ventral horn atrophy, measured as the volume of the anatomical structure, was also significantly improved in L-NAT-treated $\mathrm{mSOD} 1^{\mathrm{G} 93 \mathrm{~A}}$ ALS mice compared with vehicle-treated group, and gross atrophy in white matter, grey matter and the total cross-sectional spinal cord at lumbar level were significantly reduced by $12.6 \%, 13.2 \%$ and $12.5 \%$ respectively (Fig. 3G). Our results demonstrate that L-NAT treatment repressed motor neuron loss in the spinal cords of mSOD ${ }^{\mathrm{G} 93 \mathrm{~A}}$ ALS mice.

\section{Rescue of mitochondrial collapse and apoptotic pathways by L-NAT}

Accumulating evidence indicates that mSOD1 likely induces selective vulnerability of motor neurons through mitochondrial dysfunction and oxidative damage in ALS. We next evaluated whether LNAT exerts its neuroprotective properties through interfering in mitochondrial apoptotic pathways.

Bcl-xL, an anti-apoptotic molecule, is a Bcl-2 family member that resides in the outer mitochondrial wall and inhibits cytochrome c release. Compared with nontransgenic and asymptomatic transgenic mSOD1 mice, there are strikingly fewer Bcl-xL-positive neurons in the spinal cord of early symptomatic transgenic mSOD1 mice, and even fewer in end-stage transgenic mSOD1 mice (Vukosavic et al., 1999). In our study, western blot analysis showed that Bcl-xL was indeed reduced in end-stage mSOD1 ${ }^{\mathrm{G} 93 \mathrm{~A}}$ ALS mice but increased in L-NAT-treated mSOD1 ${ }^{\mathrm{G} 93 \mathrm{~A}}$ ALS mice (Fig. 4A).

The release of cytochrome $\mathrm{c}$ has been detected in spinal cord tissue of mSOD1 ${ }^{\mathrm{G} 93 \mathrm{~A}}$ ALS mice and has been implicated as an important cause of neuronal cell death in models of ALS (Guegan et al., 2001; Zhu et al., 2002; Ryu et al., 2005; Wang et al., 2007; Zhang et al., 2013). To determine whether L-NAT also targets the release of cytochrome $\mathrm{c}$ in an animal model, we carried out tests in mSOD1 ${ }^{\mathrm{G} 93 \mathrm{~A}}$ ALS transgenic mice. We demonstrated that, consistent with the findings in purified mitochondria (Wang et $a l ., 2008$ ) and in NSC-34 motoneurons (unpublished paper), L-NAT (at both 30 and $15 \mathrm{mg} / \mathrm{kg}$ ) significantly inhibited cytochrome c release in ALS mice (Fig. 4B).

The release of smac from mitochondria is likely related to the formation of spheroids or motoneuron death in ALS (Nagao et al., 2003). The level of AIF expression increased in the spinal cord 
of $\mathrm{mSOD}^{\mathrm{G} 93 \mathrm{~A}}$ transgenic mice as the disease progresses (Oh et al., 2006; Tanaka et al., 2010). Our observation regarding release of apoptogenic factors smac and AIF in the spinal cords of symptomatic mSOD1 ${ }^{\mathrm{G} 93 \mathrm{~A}}$ transgenic mice is consistent with earlier reports (Oh et al., 2006; Tanaka et al., 2010; Zhang et al., 2013). Moreover, L-NAT significantly inhibited smac and AIF release in treated ALS mice (Fig. $4 B$ ). Taken together, these results suggest that neuroprotection of L-NAT in ALS mice is brought about at least partially through the attenuation of the release of mitochondrial apoptogenic factors.

The activation of "executioner" caspase-3, acting downstream of mitochondrial events, has been widely reported in the $\mathrm{mSOD} 1^{\mathrm{G} 93 \mathrm{~A}}$ mouse model (Li et al., 2000a; Pasinelli et al., 2000; Tokuda et al., 2007; Wang et al., 2007; Zhang et al., 2013). We measured the levels of caspase-3 in total lysate of spinal cord samples from ALS mice treated with either saline or L-NAT and from age-matched WT mice by western blots (Fig. 4C). The level of activated caspase-3 was higher in ALS mice compared to WT animals. L-NAT significantly inhibited caspase 3 activation in ALS mice (Fig. 4C). Our data demonstrated that L-NAT inhibits both caspase-dependent (cytochrome c, smac, and caspase-3) and caspase-independent (AIF) mitochondrial cell death pathways in cellular and animal models of ALS.

\section{L-NAT is not a mitochondrial permeability transition inhibitor in isolated mitochondria}

The mitochondrial permeability transition pore consists of a multimeric complex of proteins that spans the inner and outer membranes (Crompton et al., 1999). Its opening is a sign of mitochondrial dysfunction and results from biochemical stresses such as high concentrations of $\mathrm{Ca}^{2+}$ ion or proapoptotic cytosolic proteins (Stavrovskaya et al., 2004; Rasola \& Bernardi, 2011; Zhou et al., 2014). Mitochondrial swelling can be used as a marker to monitor the induction of mitochondrial permeability transition (mPT). Such swelling is an early pathological feature associated with ALS (Gurney et al., 1994), and cytoplasmic microvacuolation attributed to mitochondrial swelling has been reported to be the conspicuous phenotype indicating degeneration of motor neurons in $\mathrm{mSOD}^{\mathrm{G} 93 \mathrm{~A}}$ transgenic mice (Jaarsma, 2006; Martin et al., 2007). Having observed that NAT inhibited cytochrome c/smac/AIF release, we next tested whether LNAT affects $\mathrm{mPT}$ in purified mitochondria using a mitochondrial swelling assay. Swelling was stimulated by the addition of exogenous $\mathrm{Ca}^{2+}$ alone or in the presence of L-NAT or CsA (the prototype inhibitor of mPT). $t_{50}$ represents the time required for $\mathrm{Ca}^{2+}$ to induce swelling in $50 \%$ of the mitochondrial population. Our experiments demonstrate that $\mathrm{CsA}$ indeed delayed $\mathrm{Ca}^{2+}$-induced mitochondrial swelling; however, LNAT did not affect $t_{50}$ in isolated mitochondria (Fig. 4D). These data indicate that L-NAT is not a direct mPT inhibitor.

\section{L-NAT suppresses astrocytic and microglial activation in the spinal cord of mSOD ${ }^{G 93 A}$ ALS mice}

Since L-NAT has been reported to reduce neuroinflammation as well as improve motor function in mouse models of early Parkinson's disease (Thornton \& Vink, 2012), we tested whether L-NAT is effective in the treatment of ALS as an anti-inflammatory agent.

Astrocytes and microglia in the spinal cord are triggered during the pathogenesis of ALS and cause damage to motor neurons and further exacerbate the loss of motor neurons and impairment of motor function. GFAP is expressed abundantly and almost exclusively in astrocytes of the CNS, and Iba1 is a microglial marker. Gradually increased expression of GFAP signals astroglial activation and gliosis, while increased expression of Ibal reflects microglial activation (Levine et al., 1999; Sunyach et al., 2012). Consistent with earlier reports (Guan et al., 2007; Yu et al., 2013; Zhang et al., 2013; Cui et al., 2014), our western blot analysis of spinal cord revealed dramatically higher levels of GFAP and Iba1 in mSOD1 ${ }^{\mathrm{G} 93 \mathrm{~A}}$ mice at 13-14 and 17-18 weeks of age compared with litter-matched WT mice. Interestingly, these pathological changes were significantly reduced by L-NAT treatment in $\mathrm{mSOD} 1^{\mathrm{G} 93 \mathrm{~A}}$ mice (Fig. 5A). Moreover, immunostaining histological sections of spinal cord further supports the western blot data by showing much higher levels of GFAP and Iba1 in $\mathrm{mSOD} 1^{\mathrm{G} 93 \mathrm{~A}}$ mice compared to litter-matched WT mice, whereas L-NAT significantly reduced the expression of GFAP and Ibal in the ventral horn (Fig. 5B). Thus our results demonstrate that L-NAT treatment reduced GFAP and Iba1 immunoreactivity in 
mSOD1 ${ }^{\mathrm{G} 93 \mathrm{~A}}$ mice, implying that L-NAT may be useful as a novel anti-inflammatory agent in the treatment of ALS.

\section{$L-N A T$ inhibits the downregulation of $N K-1 R$}

NK-1R is widely distributed in the central and peripheral nervous systems (Mantyh, 2002) and is involved in a variety of physical and pathological processes (Quartara \& Maggi, 1998; Saria, 1999). NK1R has been found to be reduced in the ventral horn of the spinal cord in patients with ALS (Dietl et al., 1989). We tested whether the expression of $\mathrm{NK}-1 \mathrm{R}$ is reduced in $\mathrm{mSOD} 1^{\mathrm{G} 93 \mathrm{~A}}$ mice.

Our western blot analysis and immunostaining results demonstrate that NK-1R is downregulated in mSOD1 ${ }^{\mathrm{G} 93 \mathrm{~A}}$ mice compared with WT mice in 13-14 and 17-18 weeks (Fig. 6A and 6B). To provide further proof of principle for the molecular mechanisms underlying the neuroprotective effects of L-NAT, we investigated its effects on NK-1R in ALS mice. The chronic administration of L-NAT, a NK-1R antagonist, significantly attenuated the reduction of NK-1R in lumbar spinal cord of late-stage ALS mice in 17-18 weeks compared with WT littermates (Fig. 6A and 6B), which is consistent with a previous report in humans (Dietl et al., 1989). Thus our results demonstrate that NK-1R downregulates in ALS mice, while the NK-1R antagonist L-NAT reduces its downregulation.

\section{DISCUSSION}

L-tryptophan is an essential amino acid for human and animal bodies. The major metabolites of Ltryptophan includes L-NAT, serotonin, and kynurenine (Heuther et al., 1992). The positive correlation between platelet serotonin levels and survival of ALS patients strongly suggests that serotonin influences the course of ALS disease, while kynurenine pathway has been reported to play an important role in the pathogenesis of ALS (Blasco et al., 2013). N-acetyl-tryptophan was originally selected from a library of 1040 compounds as a potential inhibitor of cytochrome c release. This report that L-NAT is neuroprotective in an animal model of ALS therefore provides further support for the usefulness of an isolated mitochondrial screen to identify neuroprotective agents (Wang et al., 2008). This finding is consistent with other demonstrations that L-NAT, the metabolite of L-tryptophan, is neuroprotective in experimental models of Parkinson's disease (Thornton \& Vink, 2012), traumatic brain injury (Vink et al., 2004; Donkin et al., 2009; Donkin et al., 2010), stroke (Turner et al., 2005), and opioid withdrawal (Tumati et al., 2012), and supports the contention that pharmacological interventions that inhibit cytochrome c release can slow disease progression in ALS (Guegan et al., 2001; Zhu et al., 2002; Ryu et al., 2005; Wang et al., 2007; Zhang et al., 2013). Accumulated evidence supports that the interventions targeting apoptosis or promoting anti-apoptotic molecule show promise for ALS treatment. Our findings indicate that L-NAT, although no direct impact on the opening of $\mathrm{mPTP}$ in isolated mitochondria, enhances the expression of Bcl-xL, blocks both the caspase-dependent (cytochrome $\mathrm{c}$ and smac/Diablo) and -independent (AIF) apoptotic pathways, and reduces the activation of caspase-3. Thus, L-NAT may be a potential intervention for ALS.

This observation of L-NAT is not a direct mPT inhibitor contrasts with data on other agents, such as tricyclic antidepressants and phenothiazine-derived antipyschotics identified in the library of 1040 compounds using a screen targeting mPT inhibitors (Stavrovskaya et al., 2004), but these data are consistent with our previous reports on methazolamide, melatonin, and $\mathrm{N}$-acetyl-serotonin, three other potential therapeutic agents in the library of 1040 compounds and identified in the library of 1040 compounds by a screen targeting cytochrome c release (Wang et al., 2008; Wang et al., 2009; Zhou et al., 2014). Though they are neuroprotectants and inhibitors of cytochrome c release, they do not interfere with mPT induction in isolated mitochondria (Wang et al., 2008; Wang et al., 2009). The data are also consistent with effects mediated outside the inner mitochondrial membrane/matrix, including potential targets such as Bcl-2 family members and the elements involved in release of proapoptotic proteins. Our studies suggest that L-NAT does not act directly on the inhibition of mPT induction in a purified mitochondrial system. Thus the inhibitory effects of L-NAT on cytochrome c/smac/AIF release in mSOD1G93A mice may not be the result of direct interference with mPT. 
Transgenic animal models of ALS show signs of inflammatory response at all stages of the disease, and anti-inflammatory agents targeting inflammatory pathways have been reported in animal models of ALS that demonstrate beneficial effects on survival extension (Drachman et al., 2002; Wu et al., 2003; West et al., 2004; Kiaei et al., 2005a; Kiaei et al., 2005b; Schutz et al., 2005; Kiaei et al., 2006; Shoemaker et al., 2007). Anti-inflammation therapeutic strategies, including using inflammation suppressors or modulators, could be promising interventions for ALS (Pandya et al., 2013; Zhu et al., 2015).

Cholinergic muscarinic, GABA, glycine, melatonin receptor 1A, and TRH receptor systems have been associated with motor neuron degeneration or death in ALS (Whitehouse et al., 1983; Zhang et al., 2013). Our data show that NK-1R is significantly reduced in the lumbar spinal cord of mSOD1 ${ }^{\mathrm{G} 93 \mathrm{~A}}$ mice, which is consistent with a previous report of the reduction of NK-1R in the ventral horn of the spinal cord in ALS patients (Dietl et al., 1989). The gradual loss of NK-1R in mSOD1 ${ }^{\text {G93A }}$ ALS mice may indicate that another receptor system is associated with motor neuron degeneration or death in ALS. However, whether NK-1R alteration and/or changes of NK-1R/SP axis are the leading causes or secondary outcomes of motor neuron death remains unknown. On the other hand, the actions of NK1-R/SP depend on specific tissue and cell environment. NK-1R/SP has also been reported to be involved in the trophic role in neuron survival (Barker, 1991; Caioli et al., 2011) and implicated in tumor cell growth (Munoz et al., 2005; Singh et al., 2006; Lewis et al., 2013; Harford-Wright et al., 2014).

NK-1R alteration in response to stress has been shown to be involved in the initiation and development of inflammatory process in a variety of inflammation-associated diseases including joint injury (Weisshaar \& Winkelstein, 2014), rheumatoid arthritis (Makino et al., 2012), HIV/SIV encephalitis (Vinet-Oliphant et al., 2010), pulmonary inflammation (De Swert et al., 2009), sepsis (Etogo et al., 2008), asthma (Boot et al., 2007), and skin itch (Costa et al., 2006). Many NK-1R antagonists have been developed and employed to eliminate inflammation. The anti-inflammatory efficacy of L-NAT may improve neurological outcomes in ALS.

The NK-1R antagonist aprepitant has been approved by FDA for human patients suffering from emesis, especially that triggered by cancer chemotherapy (Quartara \& Altamura, 2006), indicating that NK-1R antagonist can offer clinical benefit with acceptable efficacy and safety in human patients. Other NK-1R antagonists including L-NAT, L-732,138, L-703,606, and others have been studied for multiple indications (Holden et al., 2009; Donkin et al., 2011; Munoz et al., 2012; Tumati et al., 2012; Tao et al., 2013). Among these NK-1R antagonists, L-NAT offers a variety of effects including suppression of neuroinflammation, improvement of impaired BBB, neuroprotection of targeted cell populations, enhancement of functional outcome, and providing nutritional value (Fujita et al., 1980). Our data of LC/MS assay indicate that L-NAT can be absorbed and cross the BBB to reach the CNS tissues and peripheral skeletal muscle, suggesting its neuroprotective effect may be centrally mediated and muscle may be an important target in exploring its neuroprotection in $\mathrm{mSOD}{ }^{\mathrm{G} 93 \mathrm{~A}}$ ALS mice. However, the accelerated disease progression in our animal trial from the accumulated toxicity of high dose of $60 \mathrm{mg} / \mathrm{kg}$ L-NAT may suggest a lower dosage if L-NAT is used in human trial.

In summary, L-NAT directly or indirectly interferes with a number of key processes relevant to ALS pathogenesis, including 1) anti-apoptotic and mitochondrial dysfunction; 2) anti-inflammation by inhibiting the enhancement of GFAP and Iba1; and 3) downregulation of NK-1R. The combination of these properties suggests its novel effects in an animal model of ALS. Thus L-NAT may be a promising candidate therapeutic for ALS treatment.

\section{ACKNOWLEDGMENTS}

We thank Dr. Hongyan Wang and Chunfeng Huo for experimental discussion. This work was supported by grants from the Muscular Dystrophy Association (to X. W.), the ALS Therapy Alliance (to X. W.), the Bill \& Melinda Gates Foundation (to X. W.), and the National Natural Science Foundation of 


\section{Figure Legends}

Fig. 1. L-NAT delays disease onset and extends survival in ALS mice. Cumulative probability of onset of rotarod deficits (A) and survival (B) in $\mathrm{mSOD} 1^{\mathrm{G} 93 \mathrm{~A}}$ transgenic mice. Survival was significantly prolonged and the onset of rotarod deficit was significantly delayed in mSOD1 mice treated with 15 and $30 \mathrm{mg} / \mathrm{kg} \mathrm{L}$ NAT compared with vehicle-treated transgenic littermates. C, Table of onset of motor deficit and mortality of ALS mice treated with L-NAT. The above data are presented analytically for age (in days) at disease onset and age at death (mortality). Data are presented as mean \pm SEM. $* * * p<0.001, * * p<0.01$, ${ }^{*} p<0.05$, test animals vs. saline-treated controls analyzed by One-Way ANOVA (C) and repeated measures t-test (D and E). D, Weekly values for body weight of drug-treated mSOD1 ${ }^{\mathrm{G} 93 \mathrm{~A}}$ mice and saline-treated $\mathrm{mSOD} 1^{\mathrm{G} 93 \mathrm{~A}}$ mice were statistically indistinguishable. E, Neurological scoring indicates improved pathological outcome in group treated with L-NAT $15 \mathrm{mg} / \mathrm{kg}$ compared with saline-treated controls, and non-impaired motor function in WT controls (E). Saline-treated ALS group, $n=31$ (16 male and 15 female); test groups injected daily with $15 \mathrm{mgkg} \mathrm{L-NAT,} n=30$ (15 male and 15 female), or 30 $\mathrm{mg} / \mathrm{kg} \mathrm{L-NAT}, n=25$ (12 male and 13 female), or $60 \mathrm{mg} / \mathrm{kg} \mathrm{L-NAT} n=24$ (11 male and 13 female). For all experiments in A-E, WT control mice were tested with saline injection $n=30$ (15 male and 15 female).

Fig. 2. LC/MS analysis of L-NAT-treated $\mathrm{mSOD} 1^{\mathrm{G} 93 \mathrm{~A}}$ mice. $\mathrm{mSOD} 1^{\mathrm{G} 93 \mathrm{~A}}$ transgenic mice received daily IP injections of $60 \mathrm{mg} / \mathrm{kg}$ or $15 \mathrm{mg} \mathrm{kg}$ (the effective dose) L-NAT or saline vehicle; the tested tissues were harvested 1 hour after final IP injection at 17-18 weeks of age, and tissue homogenates were subjected to LC/MS measurement. The concentration of L-NAT contained in the brain samples was quantified against a standard curve by LC/MS analysis to confirm the reliability of LC/MS assay (A). LC/MS analysis for the distribution of L-NAT in brain, spinal cord, and skeletal muscle of mSOD ${ }^{\mathrm{G} 93 \mathrm{~A}}$ mice that received the indicated treatment $(\mathrm{B})$.

Fig. 3. L-NAT ameliorates motor neuron loss in spinal cord of mSOD $1^{\text {G93A }}$ transgenic mice. L-NAT (15 $\mathrm{mg} / \mathrm{kg}$ ) was administrated to $\mathrm{mSOD} 1^{\mathrm{G} 93 \mathrm{~A}}$ mice by daily IP injection initiated at 6 weeks of age. At the age of 17-18 weeks, tested mice were sacrificed, and sections $(18 \mu \mathrm{m})$ of lumbar spinal cord were obtained for Nissl staining. Representative Nissl-stained sections of spinal cord revealed the gross crosssectional area (A-C) and motor-neuron content (D-F) for L-NAT- and vehicle-treated mSOD ${ }^{\mathrm{G} 93 \mathrm{~A}}$ mice as well as for age-matched WT littlemates. Compared with WT littermate controls (A, D), ventral motor neuron loss were observed in saline-treated $\mathrm{mSOD} 1^{\mathrm{G} 93 \mathrm{~A}}$ mice $(\mathrm{B}, \mathrm{E})$, whereas treatment of L-NAT ameliorated the loss of motor neurons in this area of $\mathrm{mSOD} 1^{\mathrm{G} 93 \mathrm{~A}}$ mice $(\mathrm{C}, \mathrm{F})$. Quantitative data from motor neuron counts and spinal cord area of different groups were shown and tested by One-Way ANOVA ( $n=5$ mice each group, ${ }^{\# \#} p<0.001$ vs. WT group; ${ }^{* * *} p<0.001,{ }^{* *} p<0.01$ vs. vehicle-treated mice) (G). Scale bars in panels A and D correspond to $200 \mu \mathrm{m}$ and $50 \mu \mathrm{m}$, respectively.

Fig. 4. L-NAT inhibits the mitochondrial apoptotic death pathway in $\mathrm{mSOD} 1^{\mathrm{G} 93 \mathrm{~A}}$ mice but is not a $\mathrm{mPT}$ inhibitor in isolated mitochondria. L-NAT $(15 \mathrm{mg} / \mathrm{kg})$ was administrated to $\mathrm{mSOD} 1^{\mathrm{G} 93 \mathrm{~A}}$ mice by daily IP injection initiated at 6 weeks of age. At 17-18 weeks, mice were sacrificed to harvest the whole spinal cord samples or cytosolic lysates. Western blot analysis of the whole spinal cord tissues were performed with Bcl-xL (A) and caspase-3 (C) or cytosolic lysates were performed with cytochrome c/smac/AIF (B). $\beta$-actin were used as loading controls. Densitometry was performed and analyzed with One-Way ANOVA test $(n=3-5, * * * p<0.001, * * p<0.01, * p<0.05)$. Liver mitochondria were isolated from animals to detect mPT status (D). Swelling was monitored by absorbance at $540 \mathrm{~nm}$. L-NAT was dosed at $10 \mu \mathrm{M}$. 
Fig. 5. L-NAT suppresses activated microglia and astrocytes in mSOD1 ${ }^{\mathrm{G} 93 \mathrm{~A}}$ transgenic mice. L-NAT (15 $\mathrm{mg} / \mathrm{kg}$ ) was administrated to $\mathrm{mSOD} 1^{\mathrm{G} 93 \mathrm{~A}}$ mice by daily IP injection initiated at 6 weeks of age. At 10, 1314, and 17-18 weeks, mSOD1 ${ }^{\mathrm{G} 93 \mathrm{~A}}$ mice and matched WT mice were sacrificed to harvest spinal cord tissue, either for extraction to obtain lysates $(A, C)$ or for sectioning $(B, D)$. Lysates were analyzed by western blot with a probe of GFAP (A) or Iba-1 antibodies (C), and $\beta$-actin was used as loading controls. The intensity of the bands was evaluated using densitometry and analyzed by One-Way ANOVA. Sections of lumbar spinal cord were analyzed by immunostaining with a probe of GFAP (B) or Iba-1 antibodies (D) ( $\mathrm{n}=3-5$ for WT mice and $\mathrm{n}=3-5$ for ALS mice, $\left.{ }^{*} p<0.05,{ }^{*} p<0.01\right)$. The staining is a representative of $\mathrm{mSOD} 1^{\mathrm{G} 93 \mathrm{~A}}$ mice received daily IP injections of L-NAT or saline vehicle or matched WT littlemates. The white rectangle indicates the ventral horn of spinal cord. Scale bars in panels B and D correspond to 200 and $50 \mu \mathrm{m}$.

Fig. 6. L-NAT restores reduced NK-1R levels in $\mathrm{mSOD} 1^{\mathrm{G} 93 \mathrm{~A}}$ mice. L-NAT $(15 \mathrm{mg} / \mathrm{kg})$ was administrated to $\mathrm{mSOD} 1{ }^{\mathrm{G} 93 \mathrm{~A}}$ mice by daily IP injection initiated at 6 weeks of age. At 10, 13-14, and 1718 weeks, $\mathrm{mSOD} 1^{\mathrm{G} 93 \mathrm{~A}}$ mice and matched WT mice were sacrificed to harvest spinal cord tissue, either for extraction to obtain lysates (A) or for sectioning (B and C). Samples were analyzed by western blot (A) or immunostaining (B and $\mathrm{C}$ ) with antibodies to NK-1R, NeuN, GFAP, and Iba1. The representative staining demonstrated the expression of $\mathrm{NK}-1 \mathrm{R}$ in the spinal cord of $\mathrm{mSOD} 1{ }^{\mathrm{G} 93 \mathrm{~A}}$ mice received daily IP injections of L-NAT or saline vehicle or matched WT littlemates. Scale bars correspond to $200 \mu \mathrm{m}$ (B, left panel) and $50 \mu \mathrm{m}(\mathrm{B}$, middle panel and right panel). The dashed and solid rectangles represent the anterior and posterior horn of spinal cord, respectively. Arrows indicate the cells coexpression of NK-1R and other cell type markers.

\section{REFERENCES}

Baranov, S.V., Stavrovskaya, I.G., Brown, A.M., Tyryshkin, A.M. \& Kristal, B.S. (2008) Kinetic model for $\mathrm{Ca} 2+-$ induced permeability transition in energized liver mitochondria discriminates between inhibitor mechanisms. J Biol Chem, 283, 665-676.

Barker, R. (1991) Substance P and neurodegenerative disorders. A speculative review. Neuropeptides, 20, 73-78.

Blasco, H., Corcia, P., Pradat, P.F., Bocca, C., Gordon, P.H., Veyrat-Durebex, C., Mavel, S., NadalDesbarats, L., Moreau, C., Devos, D., Andres, C.R. \& Emond, P. (2013) Metabolomics in cerebrospinal fluid of patients with amyotrophic lateral sclerosis: an untargeted approach via highresolution mass spectrometry. Journal of proteome research, 12, 3746-3754.

Boot, J.D., de Haas, S., Tarasevych, S., Roy, C., Wang, L., Amin, D., Cohen, J., Sterk, P.J., Miller, B., Paccaly, A., Burggraaf, J., Cohen, A.F. \& Diamant, Z. (2007) Effect of an NK1/NK2 receptor antagonist on airway responses and inflammation to allergen in asthma. American journal of respiratory and critical care medicine, 175, 450-457.

Brahmachari, S., Fung, Y.K. \& Pahan, K. (2006) Induction of glial fibrillary acidic protein expression in astrocytes by nitric oxide. The Journal of neuroscience : the official journal of the Society for Neuroscience, 26, 4930-4939.

Caioli, S., Curcio, L., Pieri, M., Antonini, A., Marolda, R., Severini, C. \& Zona, C. (2011) Substance P receptor activation induces downregulation of the AMPA receptor functionality in cortical neurons from a genetic model of Amyotrophic Lateral Sclerosis. Neurobiology of disease, 44, 92-101.

Chen, Y., Guan, Y., Liu, H., Wu, X., Yu, L., Wang, S., Zhao, C., Du, H. \& Wang, X. (2012a) Activation of the Wnt/beta-catenin signaling pathway is associated with glial proliferation in the adult spinal cord of ALS transgenic mice. Biochemical and biophysical research communications, 420, 397 403. 
Chen, Y., Guan, Y., Zhang, Z., Liu, H., Wang, S., Yu, L., Wu, X. \& Wang, X. (2012b) Wnt signaling pathway is involved in the pathogenesis of amyotrophic lateral sclerosis in adult transgenic mice. Neurological research, 34, 390-399.

Costa, S.K., Starr, A., Hyslop, S., Gilmore, D. \& Brain, S.D. (2006) How important are NK1 receptors for influencing microvascular inflammation and itch in the skin? Studies using Phoneutria nigriventer venom. Vascular pharmacology, 45, 209-214.

Crompton, M., Virji, S., Doyle, V., Johnson, N. \& Ward, J.M. (1999) The mitochondrial permeability transition pore. Biochem Soc Symp, 66, 167-179.

Cui, Y., Masaki, K., Yamasaki, R., Imamura, S., Suzuki, S.O., Hayashi, S., Sato, S., Nagara, Y., Kawamura, M.F. \& Kira, J. (2014) Extensive dysregulations of oligodendrocytic and astrocytic connexins are associated with disease progression in an amyotrophic lateral sclerosis mouse model. Journal of neuroinflammation, 11, 42.

De Swert, K.O., Bracke, K.R., Demoor, T., Brusselle, G.G. \& Joos, G.F. (2009) Role of the tachykinin NK1 receptor in a murine model of cigarette smoke-induced pulmonary inflammation. Respiratory research, 10, 37.

Dietl, M.M., Sanchez, M., Probst, A. \& Palacios, J.M. (1989) Substance P receptors in the human spinal cord: decrease in amyotrophic lateral sclerosis. Brain research, 483, 39-49.

Donkin, J.J., Cernak, I., Blumbergs, P.C. \& Vink, R. (2010) A substance P antagonist reduces axonal injury and improves neurologic outcome when administered up to $12 \mathrm{~h}$ following traumatic brain injury. J Neurotrauma.

Donkin, J.J., Cernak, I., Blumbergs, P.C. \& Vink, R. (2011) A substance P antagonist reduces axonal injury and improves neurologic outcome when administered up to 12 hours after traumatic brain injury. Journal of neurotrauma, 28, 217-224.

Donkin, J.J., Nimmo, A.J., Cernak, I., Blumbergs, P.C. \& Vink, R. (2009) Substance P is associated with the development of brain edema and functional deficits after traumatic brain injury. $J$ Cereb Blood Flow Metab, 29, 1388-1398.

Drachman, D.B., Frank, K., Dykes-Hoberg, M., Teismann, P., Almer, G., Przedborski, S. \& Rothstein, J.D. (2002) Cyclooxygenase 2 inhibition protects motor neurons and prolongs survival in a transgenic mouse model of ALS. Annals of neurology, 52, 771-778.

Etogo, A.O., Nunez, J., Lin, C.Y., Toliver-Kinsky, T.E. \& Sherwood, E.R. (2008) NK but not CD1restricted NKT cells facilitate systemic inflammation during polymicrobial intra-abdominal sepsis. Journal of immunology, 180, 6334-6345.

Fujita, Y., Anzai, M., Inui, M., Nishimoto, T. \& Inoue, G. (1980) Utilization of N-acetyl-L-tryptophan given intravenously to unrestrained adult rats. Journal of nutritional science and vitaminology, 26, 381-388.

Gill, A., Kidd, J., Vieira, F., Thompson, K. \& Perrin, S. (2009) No benefit from chronic lithium dosing in a sibling-matched, gender balanced, investigator-blinded trial using a standard mouse model of familial ALS. PloS one, 4, e6489.

Guan, Y.J., Wang, X., Wang, H.Y., Kawagishi, K., Ryu, H., Huo, C.F., Shimony, E.M., Kristal, B.S., Kuhn, H.G. \& Friedlander, R.M. (2007) Increased stem cell proliferation in the spinal cord of adult amyotrophic lateral sclerosis transgenic mice. Journal of neurochemistry, 102, 1125-1138.

Guegan, C., Vila, M., Rosoklija, G., Hays, A.P. \& Przedborski, S. (2001) Recruitment of the mitochondrial-dependent apoptotic pathway in amyotrophic lateral sclerosis. The Journal of neuroscience : the official journal of the Society for Neuroscience, 21, 6569-6576.

Gurney, M.E., Pu, H., Chiu, A.Y., Dal Canto, M.C., Polchow, C.Y., Alexander, D.D., Caliendo, J., Hentati, A., Kwon, Y.W., Deng, H.X. \& et al. (1994) Motor neuron degeneration in mice that express a human $\mathrm{Cu}, \mathrm{Zn}$ superoxide dismutase mutation. Science, 264, 1772-1775.

Harford-Wright, E., Lewis, K.M., Vink, R. \& Ghabriel, M.N. (2014) Evaluating the role of substance P in the growth of brain tumors. Neuroscience, 261, 85-94. 
Heuther, G., Hajak, G., Reimer, A., Poeggeler, B., Blomer, M., Rodenbeck, A. \& Ruther, E. (1992) The metabolic fate of infused L-tryptophan in men: possible clinical implications of the accumulation of circulating tryptophan and tryptophan metabolites. Psychopharmacology, 109, 422-432.

Holden, J.E., Pizzi, J.A. \& Jeong, Y. (2009) An NK1 receptor antagonist microinjected into the periaqueductal gray blocks lateral hypothalamic-induced antinociception in rats. Neuroscience letters, 453, 115-119.

Jaarsma, D. (2006) Swelling and vacuolisation of mitochondria in transgenic SOD1-ALS mice: a consequence of supranormal SOD1 expression? Mitochondrion, 6, 48-49; author reply 50-41.

Kaneb, H.M., Sharp, P.S., Rahmani-Kondori, N. \& Wells, D.J. (2011) Metformin treatment has no beneficial effect in a dose-response survival study in the SOD1(G93A) mouse model of ALS and is harmful in female mice. PloS one, 6, e24189.

Kiaei, M., Kipiani, K., Chen, J., Calingasan, N.Y. \& Beal, M.F. (2005a) Peroxisome proliferator-activated receptor-gamma agonist extends survival in transgenic mouse model of amyotrophic lateral sclerosis. Experimental neurology, 191, 331-336.

Kiaei, M., Kipiani, K., Petri, S., Chen, J., Calingasan, N.Y. \& Beal, M.F. (2005b) Celastrol blocks neuronal cell death and extends life in transgenic mouse model of amyotrophic lateral sclerosis. Neuro-degenerative diseases, 2, 246-254.

Kiaei, M., Petri, S., Kipiani, K., Gardian, G., Choi, D.K., Chen, J., Calingasan, N.Y., Schafer, P., Muller, G.W., Stewart, C., Hensley, K. \& Beal, M.F. (2006) Thalidomide and lenalidomide extend survival in a transgenic mouse model of amyotrophic lateral sclerosis. The Journal of neuroscience : the official journal of the Society for Neuroscience, 26, 2467-2473.

Levine, J.B., Kong, J., Nadler, M. \& Xu, Z. (1999) Astrocytes interact intimately with degenerating motor neurons in mouse amyotrophic lateral sclerosis (ALS). Glia, 28, 215-224.

Lewis, K.M., Harford-Wright, E., Vink, R. \& Ghabriel, M.N. (2013) NK1 receptor antagonists and dexamethasone as anticancer agents in vitro and in a model of brain tumours secondary to breast cancer. Anti-cancer drugs, 24, 344-354.

Li, M., Ona, V.O., Chen, M., Kaul, M., Tenneti, L., Zhang, X., Stieg, P.E., Lipton, S.A. \& Friedlander, R.M. (2000a) Functional role and therapeutic implications of neuronal caspase-1 and -3 in a mouse model of traumatic spinal cord injury. Neuroscience, 99, 333-342.

Li, M., Ona, V.O., Guegan, C., Chen, M., Jackson-Lewis, V., Andrews, L.J., Olszewski, A.J., Stieg, P.E., Lee, J.P., Przedborski, S. \& Friedlander, R.M. (2000b) Functional role of caspase-1 and caspase-3 in an ALS transgenic mouse model. Science, 288, 335-339.

Li, X., Guan, Y., Chen, Y., Zhang, C., Shi, C., Zhou, F., Yu, L., Juan, J. \& Wang, X. (2013) Expression of Wnt5a and its receptor Fzd2 is changed in the spinal cord of adult amyotrophic lateral sclerosis transgenic mice. International journal of clinical and experimental pathology, 6, 1245-1260.

Makino, A., Sakai, A., Ito, H. \& Suzuki, H. (2012) Involvement of tachykinins and NK1 receptor in the joint inflammation with collagen type II-specific monoclonal antibody-induced arthritis in mice. Journal of Nippon Medical School = Nippon Ika Daigaku zasshi, 79, 129-138.

Mantyh, P.W. (2002) Neurobiology of substance P and the NK1 receptor. The Journal of clinical psychiatry, 63 Suppl 11, 6-10.

Martin, L.J., Liu, Z., Chen, K., Price, A.C., Pan, Y., Swaby, J.A. \& Golden, W.C. (2007) Motor neuron degeneration in amyotrophic lateral sclerosis mutant superoxide dismutase-1 transgenic mice: mechanisms of mitochondriopathy and cell death. J Comp Neurol, 500, 20-46.

McCombe, P.A. \& Henderson, R.D. (2011) The Role of immune and inflammatory mechanisms in ALS. Current molecular medicine, 11, 246-254.

Munoz, M., Gonzalez-Ortega, A., Rosso, M., Robles-Frias, M.J., Carranza, A., Salinas-Martin, M.V. \& Covenas, R. (2012) The substance P/neurokinin-1 receptor system in lung cancer: focus on the antitumor action of neurokinin-1 receptor antagonists. Peptides, 38, 318-325. 
Munoz, M., Rosso, M., Perez, A., Covenas, R., Rosso, R., Zamarriego, C. \& Piruat, J.I. (2005) The NK1 receptor is involved in the antitumoural action of L-733,060 and in the mitogenic action of substance $\mathrm{P}$ on neuroblastoma and glioma cell lines. Neuropeptides, 39, 427-432.

Nagao, M., Kato, S., Miyazaki, Y. \& Hayashi, H. (2003) Trace of cell death of spinal motoneutron of ALS: about the role of Smac/DIABLO. Annual Report of the Research Committee on the Neurodegenerative Diseases of the Ministry of Health, Labour and Welfare, Japan, 25-26.

Oh, Y.K., Shin, K.S. \& Kang, S.J. (2006) AIF translocates to the nucleus in the spinal motor neurons in a mouse model of ALS. Neurosci Lett, 406, 205-210.

Pandya, R.S., Zhu, H., Li, W., Bowser, R., Friedlander, R.M. \& Wang, X. (2013) Therapeutic neuroprotective agents for amyotrophic lateral sclerosis. Cellular and molecular life sciences : CMLS, 70, 4729-4745.

Pasinelli, P., Houseweart, M.K., Brown, R.H., Jr. \& Cleveland, D.W. (2000) Caspase-1 and -3 are sequentially activated in motor neuron death in $\mathrm{Cu}, \mathrm{Zn}$ superoxide dismutase-mediated familial amyotrophic lateral sclerosis. Proceedings of the National Academy of Sciences of the United States of America, 97, 13901-13906.

Quartara, L. \& Altamura, M. (2006) Tachykinin receptors antagonists: from research to clinic. Current drug targets, 7, 975-992.

Quartara, L. \& Maggi, C.A. (1998) The tachykinin NK1 receptor. Part II: Distribution and pathophysiological roles. Neuropeptides, 32, 1-49.

Rasola, A. \& Bernardi, P. (2011) Mitochondrial permeability transition in $\mathrm{Ca}(2+)$-dependent apoptosis and necrosis. Cell calcium, 50, 222-233.

Ryu, H., Smith, K., Camelo, S.I., Carreras, I., Lee, J., Iglesias, A.H., Dangond, F., Cormier, K.A., Cudkowicz, M.E., Brown, R.H., Jr. \& Ferrante, R.J. (2005) Sodium phenylbutyrate prolongs survival and regulates expression of anti-apoptotic genes in transgenic amyotrophic lateral sclerosis mice. Journal of neurochemistry, 93, 1087-1098.

Saria, A. (1999) The tachykinin NK1 receptor in the brain: pharmacology and putative functions. European journal of pharmacology, 375, 51-60.

Schiffer, D., Cordera, S., Cavalla, P. \& Migheli, A. (1996) Reactive astrogliosis of the spinal cord in amyotrophic lateral sclerosis. Journal of the neurological sciences, 139 Suppl, 27-33.

Schutz, B., Reimann, J., Dumitrescu-Ozimek, L., Kappes-Horn, K., Landreth, G.E., Schurmann, B., Zimmer, A. \& Heneka, M.T. (2005) The oral antidiabetic pioglitazone protects from neurodegeneration and amyotrophic lateral sclerosis-like symptoms in superoxide dismutaseG93A transgenic mice. The Journal of neuroscience : the official journal of the Society for Neuroscience, 25, 7805-7812.

Shoemaker, J.L., Seely, K.A., Reed, R.L., Crow, J.P. \& Prather, P.L. (2007) The CB2 cannabinoid agonist AM-1241 prolongs survival in a transgenic mouse model of amyotrophic lateral sclerosis when initiated at symptom onset. Journal of neurochemistry, 101, 87-98.

Singh, A.S., Caplan, A., Corcoran, K.E., Fernandez, J.S., Preziosi, M. \& Rameshwar, P. (2006) Oncogenic and metastatic properties of preprotachykinin-I and neurokinin-1 genes. Vascular pharmacology, 45, 235-242.

Stavrovskaya, I.G., Narayanan, M.V., Zhang, W., Krasnikov, B.F., Heemskerk, J., Young, S.S., Blass, J.P., Brown, A.M., Beal, M.F., Friedlander, R.M. \& Kristal, B.S. (2004) Clinically approved heterocyclics act on a mitochondrial target and reduce stroke-induced pathology. $J$ Exp Med, 200, 211-222.

Sunyach, C., Michaud, M., Arnoux, T., Bernard-Marissal, N., Aebischer, J., Latyszenok, V., Gouarne, C., Raoul, C., Pruss, R.M., Bordet, T. \& Pettmann, B. (2012) Olesoxime delays muscle denervation, astrogliosis, microglial activation and motoneuron death in an ALS mouse model. Neuropharmacology, 62, 2346-2352. 
Tanaka, H., Shimazaki, H., Kimura, M., Izuta, H., Tsuruma, K., Shimazawa, M. \& Hara, H. (2010) Apoptosis-Inducing Factor and Cyclophilin A Cotranslocate to the Motor Neuronal Nuclei in Amyotrophic Lateral Sclerosis Model Mice. CNS Neurosci Ther.

Tao, K., Wang, H.T., Chen, B., Wang, B.T., Li, Z.Y., Zhu, X.X., Tang, C.W. \& Hu, D.H. (2013) Effect of nonpeptide NK1 receptor antagonist L-703,606 on the edema formation in rats at early stage after deep partial-thickness skin scalding. Asian Pacific journal of tropical medicine, 6, 387-394.

Thornton, E., Hassall, M.M., Corrigan, F. \& Vink, R. (2014) The NK1 receptor antagonist N-acetyl-1tryptophan reduces dyskinesia in a hemi-parkinsonian rodent model. Parkinsonism \& related disorders.

Thornton, E. \& Vink, R. (2012) Treatment with a substance P receptor antagonist is neuroprotective in the intrastriatal 6-hydroxydopamine model of early Parkinson's disease. PloS one, 7, e34138.

Tokuda, E., Ono, S., Ishige, K., Watanabe, S., Okawa, E., Ito, Y. \& Suzuki, T. (2007) Dysequilibrium between caspases and their inhibitors in a mouse model for amyotrophic lateral sclerosis. Brain Res, 1148, 234-242.

Tumati, S., Largent-Milnes, T.M., Keresztes, A.I., Yamamoto, T., Vanderah, T.W., Roeske, W.R., Hruby, V.J. \& Varga, E.V. (2012) Tachykinin NK(1) receptor antagonist co-administration attenuates opioid withdrawal-mediated spinal microglia and astrocyte activation. European journal of pharmacology, 684, 64-70.

Turner, R.J., Blumbergs, P.C. \& Vink, R. (2005) A substance P antagonist improves outcome following reversible middle cerebral artery occlusion in rats. Journal of Cerebral Blood Flow \& Metabolism, S32.

Vinet-Oliphant, H., Alvarez, X., Buza, E., Borda, J.T., Mohan, M., Aye, P.P., Tuluc, F., Douglas, S.D. \& Lackner, A.A. (2010) Neurokinin-1 receptor (NK1-R) expression in the brains of SIV-infected rhesus macaques: implications for substance P in NK1-R immune cell trafficking into the CNS. The American journal of pathology, 177, 1286-1297.

Vink, R., Donkin, J.J., Cruz, M.I., Nimmo, A.J. \& Cernak, I. (2004) A substance P antagonist increases brain intracellular free magnesium concentration after diffuse traumatic brain injury in rats. Journal of the American College of Nutrition, 23, 538S-540S.

Vukosavic, S., Dubois-Dauphin, M., Romero, N. \& Przedborski, S. (1999) Bax and Bcl-2 interaction in a transgenic mouse model of familial amyotrophic lateral sclerosis. Journal of neurochemistry, 73, 2460-2468.

Wang, H., Guan, Y., Wang, X., Smith, K., Cormier, K., Zhu, S., Stavrovskaya, I.G., Huo, C., Ferrante, R.J., Kristal, B.S. \& Friedlander, R.M. (2007) Nortriptyline delays disease onset in models of chronic neurodegeneration. The European journal of neuroscience, 26, 633-641.

Wang, X., Zhu, S., Pei, Z., Drozda, M., Stavrovskaya, I.G., Del Signore, S.J., Cormier, K., Shimony, E.M., Wang, H., Ferrante, R.J., Kristal, B.S. \& Friedlander, R.M. (2008) Inhibitors of cytochrome c release with therapeutic potential for Huntington's disease. The Journal of neuroscience : the official journal of the Society for Neuroscience, 28, 9473-9485.

Weisshaar, C.L. \& Winkelstein, B.A. (2014) Ablating spinal NK1-bearing neurons eliminates the development of pain and reduces spinal neuronal hyperexcitability and inflammation from mechanical joint injury in the rat. The journal of pain : official journal of the American Pain Society, 15, 378-386.

West, M., Mhatre, M., Ceballos, A., Floyd, R.A., Grammas, P., Gabbita, S.P., Hamdheydari, L., Mai, T., Mou, S., Pye, Q.N., Stewart, C., West, S., Williamson, K.S., Zemlan, F. \& Hensley, K. (2004) The arachidonic acid 5-lipoxygenase inhibitor nordihydroguaiaretic acid inhibits tumor necrosis factor alpha activation of microglia and extends survival of G93A-SOD1 transgenic mice. Journal of neurochemistry, 91, 133-143.

Whitehouse, P.J., Wamsley, J.K., Zarbin, M.A., Price, D.L., Tourtellotte, W.W. \& Kuhar, M.J. (1983) Amyotrophic lateral sclerosis: alterations in neurotransmitter receptors. Annals of neurology, 14, 8-16. 
Wu, A.S., Kiaei, M., Aguirre, N., Crow, J.P., Calingasan, N.Y., Browne, S.E. \& Beal, M.F. (2003) Iron porphyrin treatment extends survival in a transgenic animal model of amyotrophic lateral sclerosis. Journal of neurochemistry, 85, 142-150.

Yu, L., Guan, Y., Wu, X., Chen, Y., Liu, Z., Du, H. \& Wang, X. (2013) Wnt Signaling is Altered by Spinal Cord Neuronal Dysfunction in Amyotrophic Lateral Sclerosis Transgenic Mice. Neurochemical research.

Zhang, Y., Cook, A., Kim, J., Baranov, S.V., Jiang, J., Smith, K., Cormier, K., Bennett, E., Browser, R.P., Day, A.L., Carlisle, D.L., Ferrante, R.J., Wang, X. \& Friedlander, R.M. (2013) Melatonin inhibits the caspase-1/cytochrome c/caspase-3 cell death pathway, inhibits MT1 receptor loss and delays disease progression in a mouse model of amyotrophic lateral sclerosis. Neurobiology of disease, 55, 26-35.

Zhou, F., Guan, Y., Chen, Y., Zhang, C., Yu, L., Gao, H., Du, H., Liu, B. \& Wang, X. (2013) miRNA-9 expression is upregulated in the spinal cord of G93A-SOD1 transgenic mice. International journal of clinical and experimental pathology, 6, 1826-1838.

Zhou, H., Wang, J., Jiang, J., Stavrovskaya, I., Li, M., Li, W., Wu, Q., Zhang, X.M., Luo, C.L., Zhou, S., Sirianni, A.C., Sarkar, S., Kristal, B., Friedlander, R.M. \& Wang, X. (2014) N-acetyl-serotonin offers neuroprotection through inhibiting mitochondrial death pathways and autophagic activation in experimental models of ischemic injury. Journal of Neuroscience, 34, 2967-2978.

Zhu, S., Stavrovskaya, I.G., Drozda, M., Kim, B.Y., Ona, V., Li, M., Sarang, S., Liu, A.S., Hartley, D.M., Wu, D.C., Gullans, S., Ferrante, R.J., Przedborski, S., Kristal, B.S. \& Friedlander, R.M. (2002) Minocycline inhibits cytochrome c release and delays progression of amyotrophic lateral sclerosis in mice. Nature, 417, 74-78.

Zhu, Y., Fotinos, A., Mao, L.L., Atassi, N., Zhou, E.W., Ahmad, S., Guan, Y., Berry, J.D., Cudkowicz, M.E. \& Wang, X. (2015) Neuroprotective agents target molecular mechanisms of disease in ALS. Drug Discov Today, 20, 65-75. 


\section{Figure 1}

A

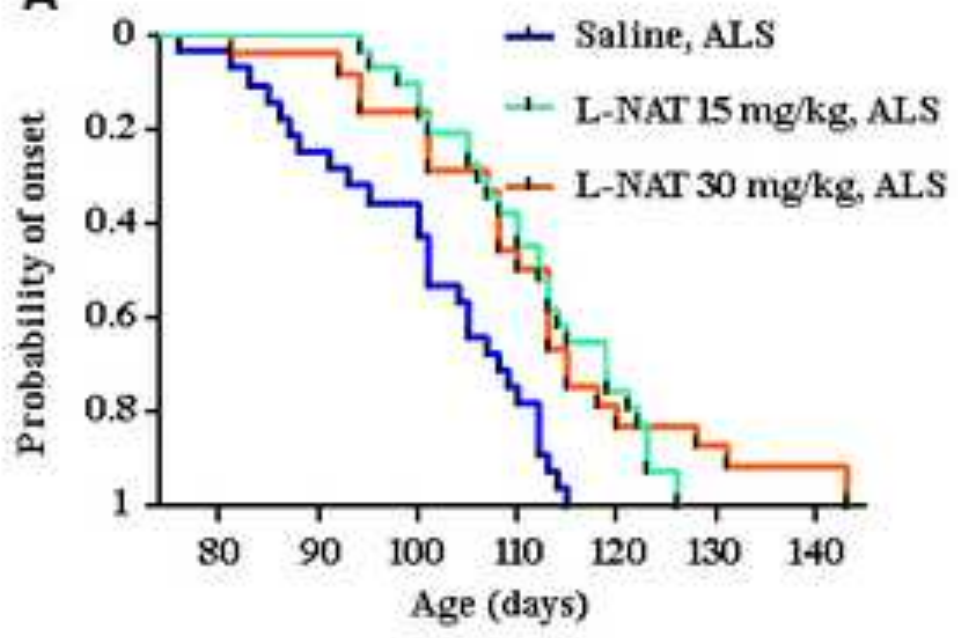

B

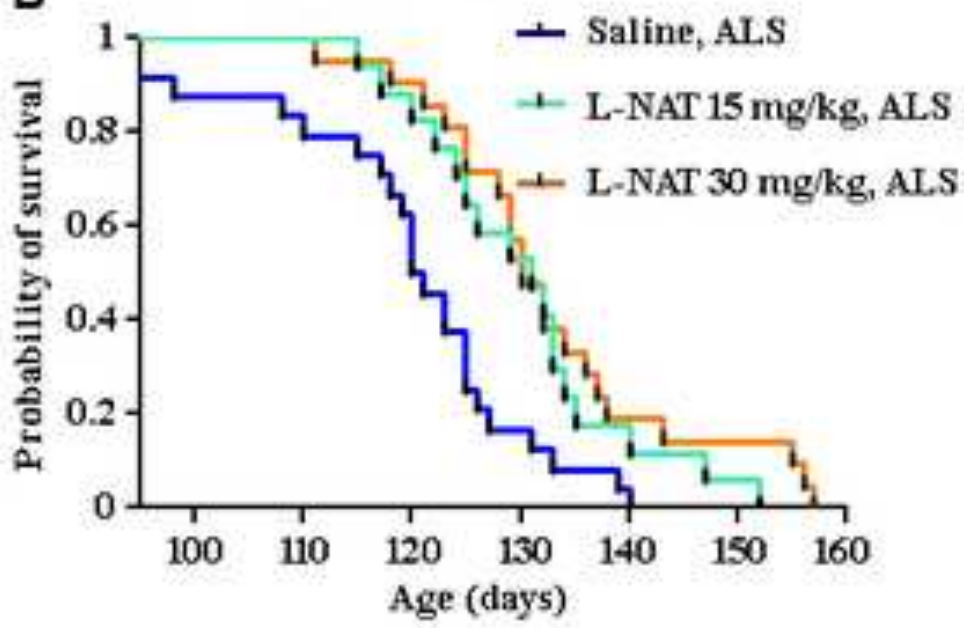

C

\begin{tabular}{|c|c|c|c|c|}
\hline & \multirow[b]{2}{*}{$\begin{array}{l}\text { Saline } \\
(n=31)\end{array}$} & \multicolumn{3}{|c|}{ L-NAT } \\
\hline & & $\begin{array}{l}15 \mathrm{mg} / \mathrm{kg} \\
(\mathrm{n}=30)\end{array}$ & $\begin{array}{l}30 \mathrm{mg} / \mathrm{kg} \\
(\mathrm{n}=25)\end{array}$ & $\begin{array}{c}60 \mathrm{mg} / \mathrm{kg} \\
(\mathrm{n}=24)\end{array}$ \\
\hline Onset & $100.3 \pm 2.1$ & $111.3 \pm 1.8^{\cdots *}$ & $111.3 \pm 3.0^{* *}$ & $101.4 \pm 2.7$ \\
\hline Mortality & $120.6 \pm 2.4$ & $130.3 \pm 2.4^{* *}$ & $132.8 \pm 2.6^{* 0}$ & $116.0 \pm 4.1$ \\
\hline
\end{tabular}
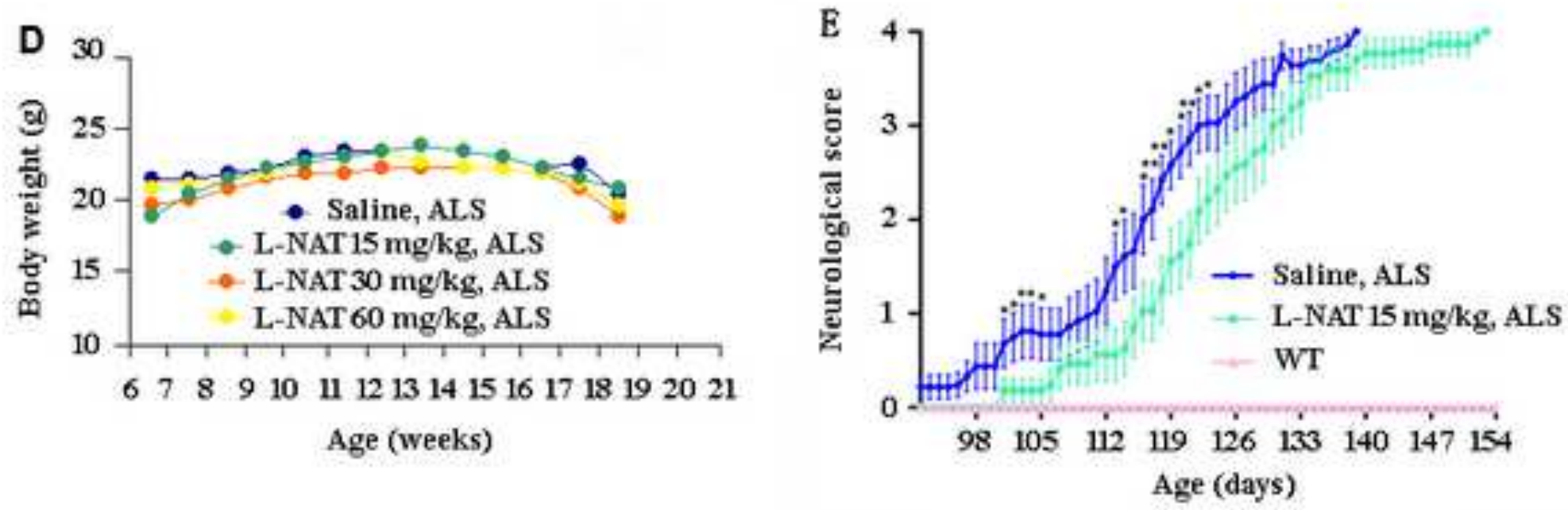


\section{Figure 2}

A

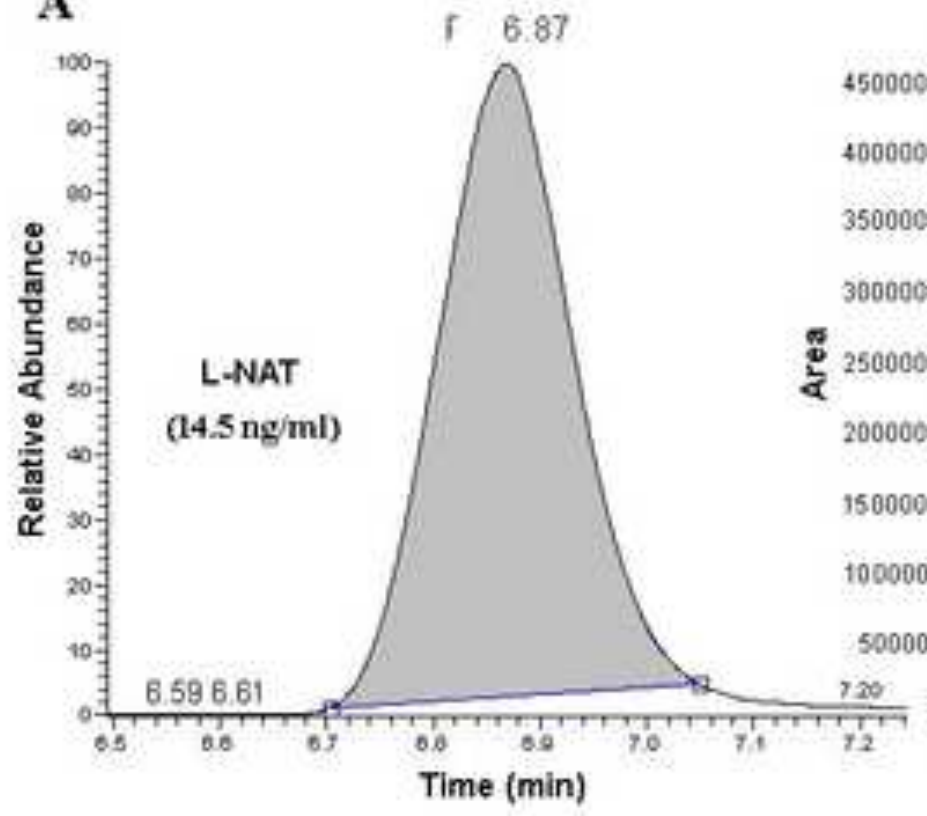

L-NAT

$f^{Y}=165612+38346.5^{*} X+39.0301^{*} X^{\wedge} 2 R^{\wedge} 2=0.9996 \mathrm{~W} \cdot 1 \mathrm{X}$ 00000 年

000007

$500000=$

000000

0000

$0000=$
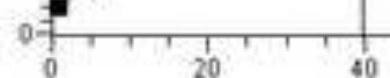

40

Pg/thI

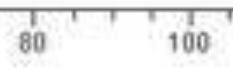

B

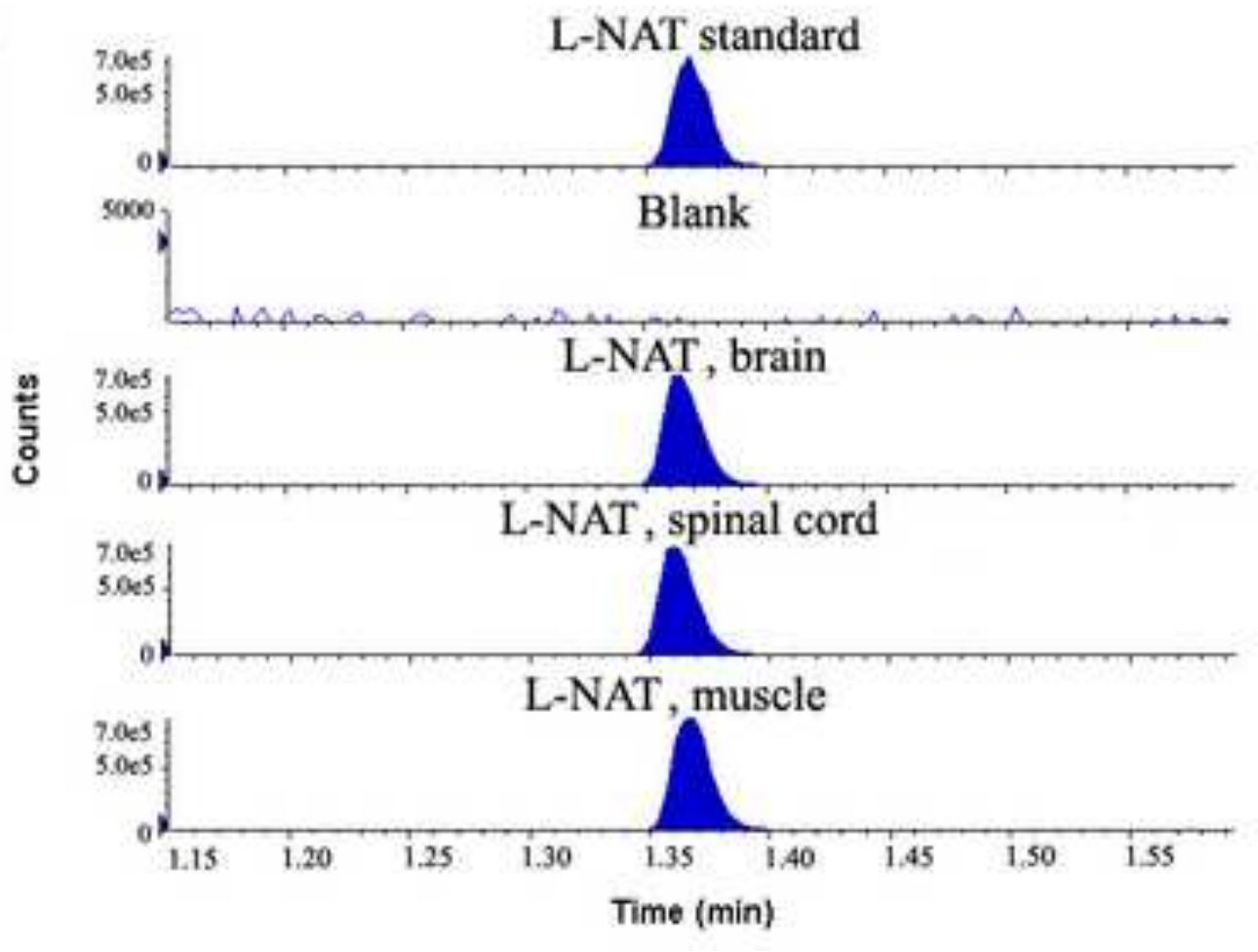


Figure 3

A

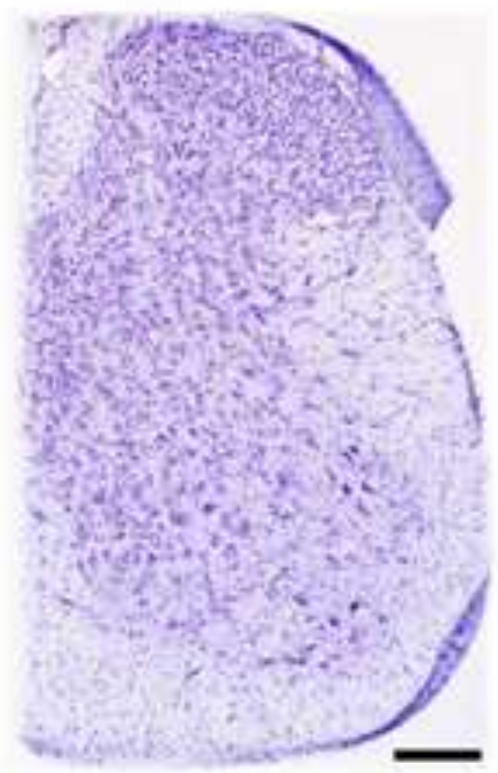

D

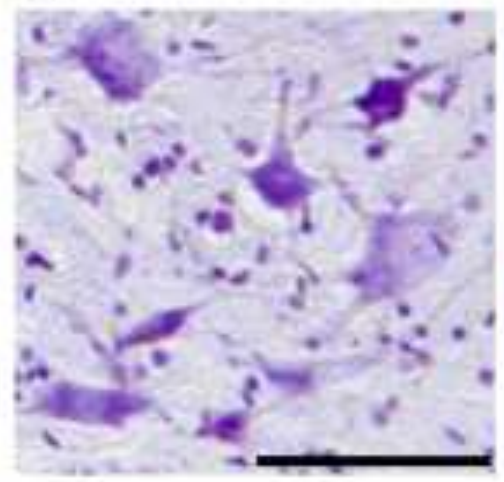

B

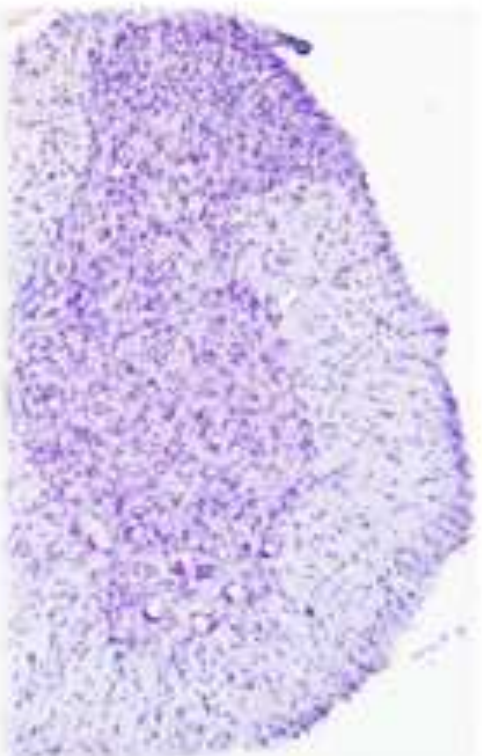

E

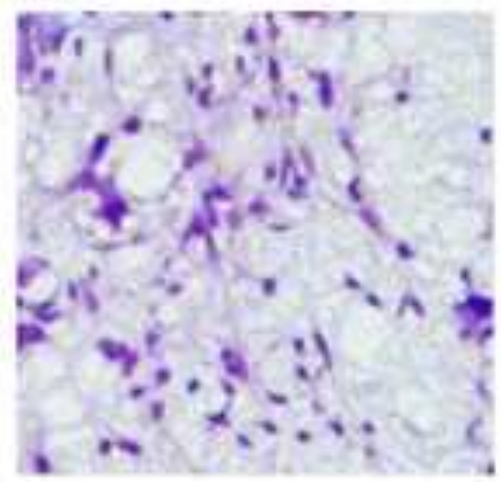

C

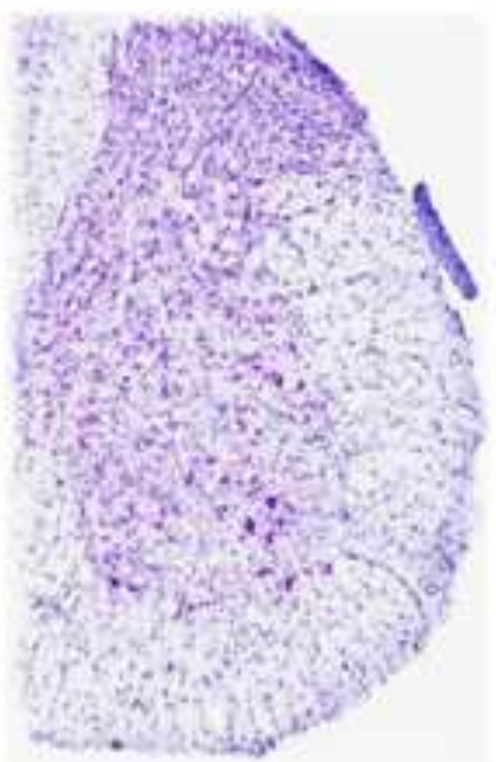

F

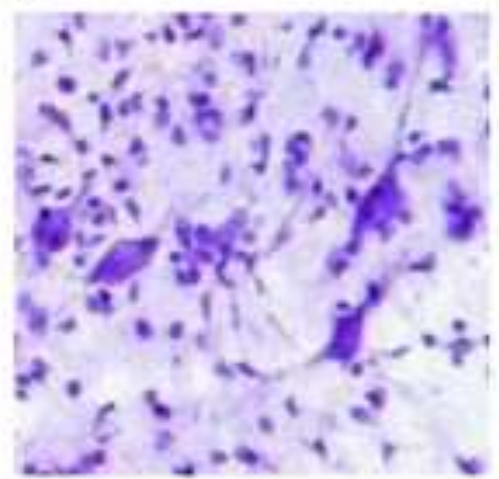

G

\begin{tabular}{|c|c|c|c|}
\hline & WT & Saline, ALS & L-NAT, ALS \\
\hline Total area $\left(\times 10^{5} \mu \mathrm{m}^{2}\right)$ & $31.0 \pm 0.4$ & $26.5 \pm 0.7^{\text {fसI }}$ & $29.8 \pm 0.4^{*}$ \\
\hline White matter $\left(\times 10^{5} \mu \mathrm{m}^{2}\right)$ & $16.1 \pm 0.3$ & $13.5 \pm 0.6^{\mathrm{nm}}$ & $15.2 \pm 0.2^{*}$ \\
\hline Grey matter $\left(\times 10^{5} \mu \mathrm{m}^{2}\right)$ & $14.9 \pm 0.2$ & $12.9 \pm 0.2^{\text {th }}$ & $14.6 \pm 0.2^{*}$ \\
\hline $\begin{array}{l}\text { Motor neuron counting } \\
\text { (number) }\end{array}$ & $10.5 \pm 1.3$ & $3.1 \pm 1.2^{\text {"mfn }}$ & $8.2 \pm 1.3^{* *+1}$ \\
\hline
\end{tabular}




\section{Figure 4}

A
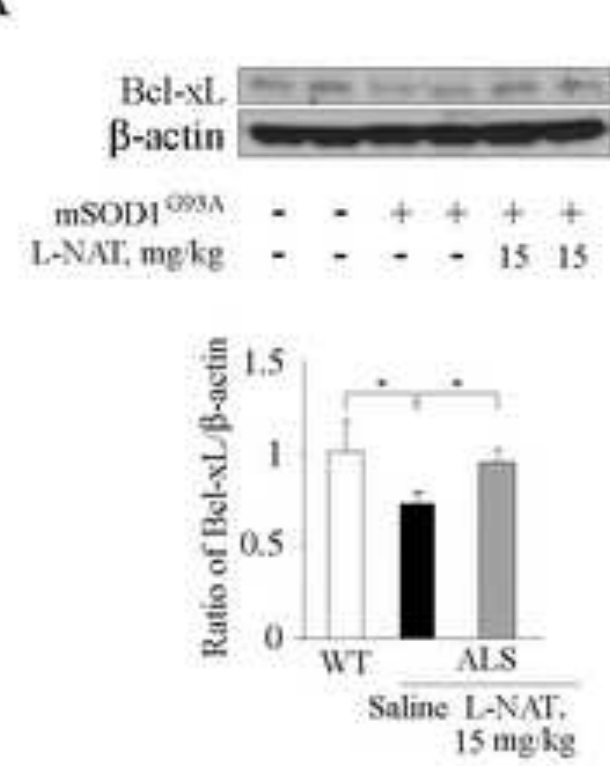

C
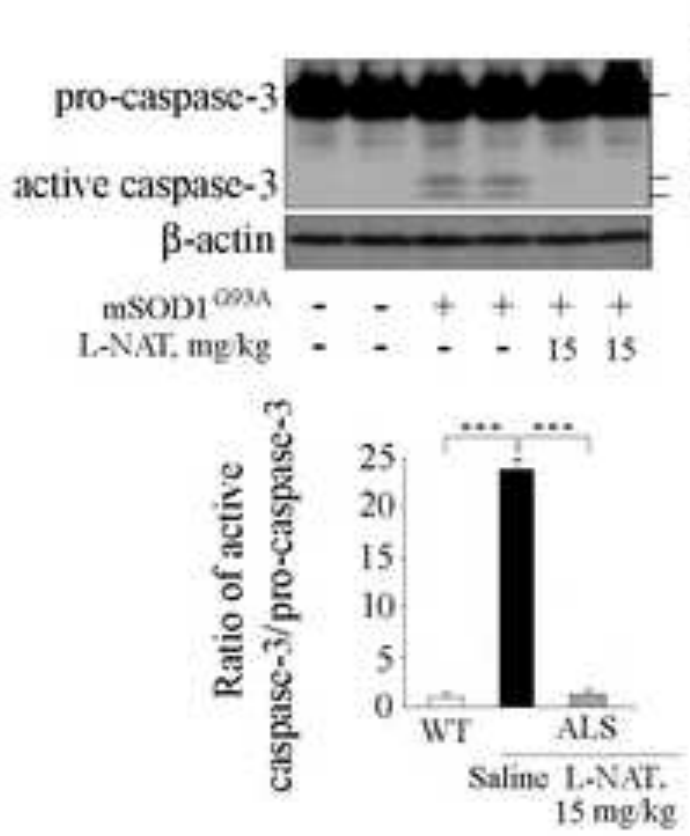

B
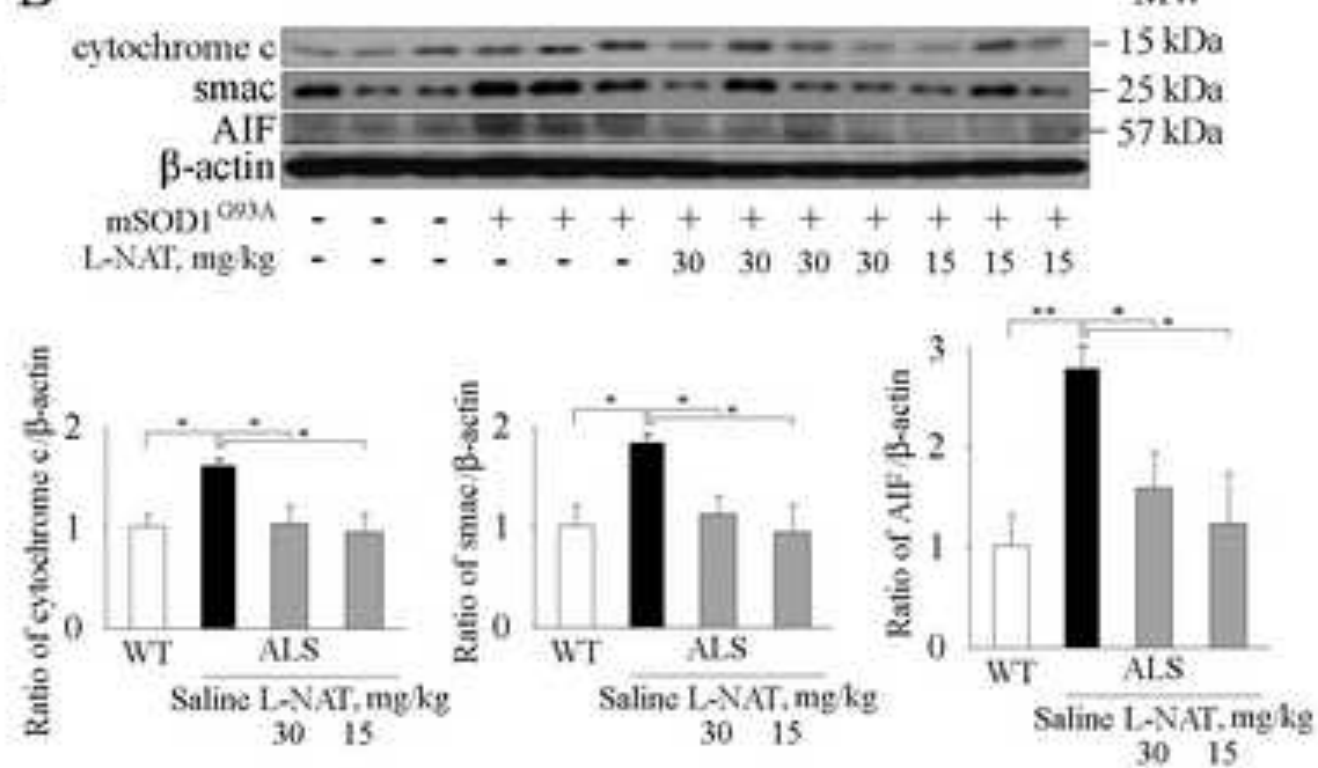

D
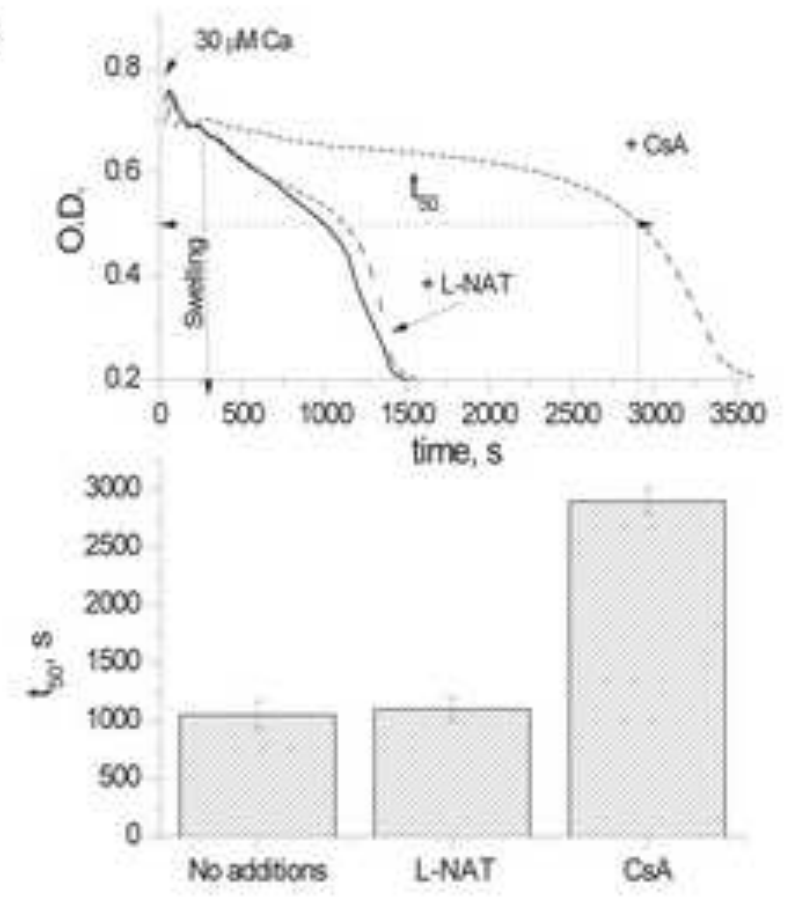

MW $32 \mathrm{kDa}$ $19 \mathrm{kJa}$ $17 \mathrm{kDa}$ 
Figure 5
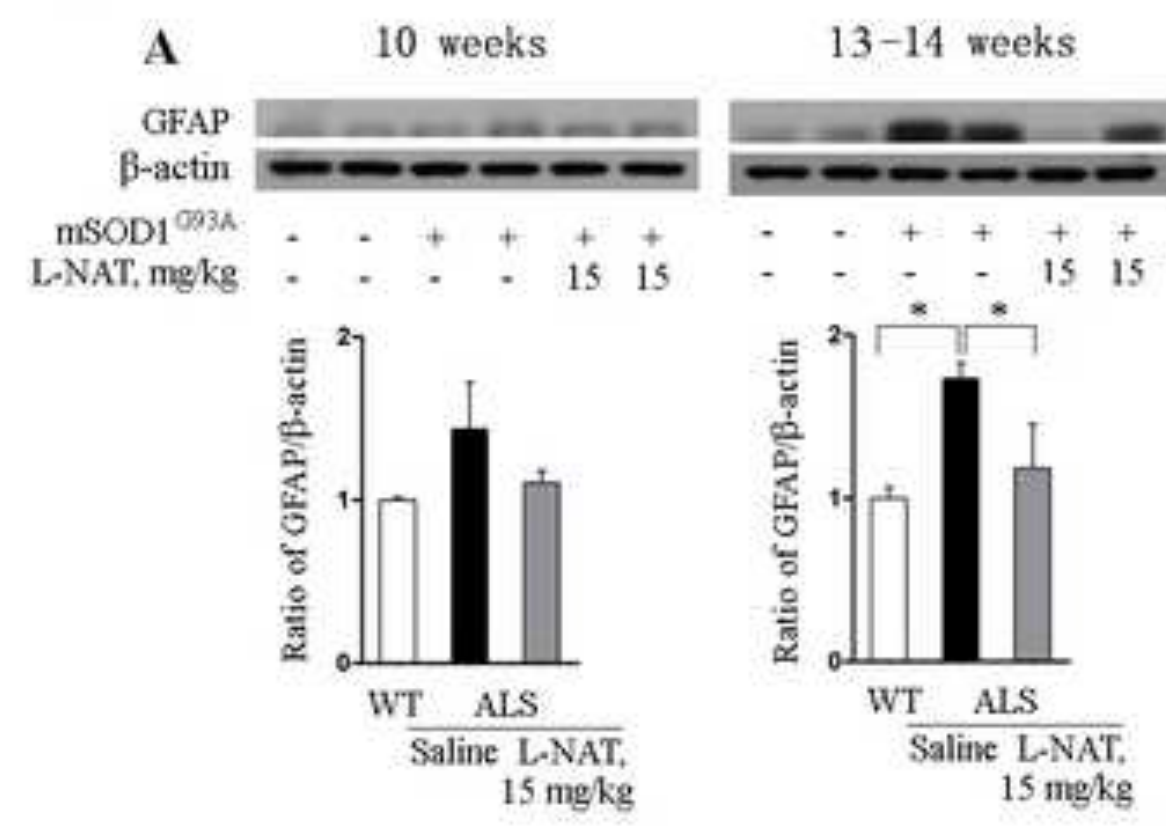

17-18 weeks
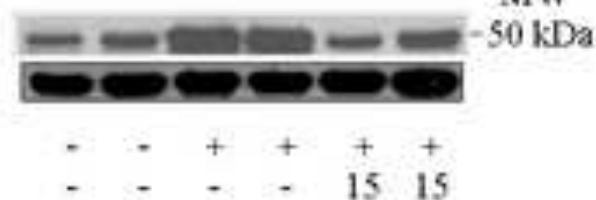

C

10 weeks

Ibal

B-actin

$\mathrm{mSOD1}^{\text {G93A }}$

L-NAT, mg/g

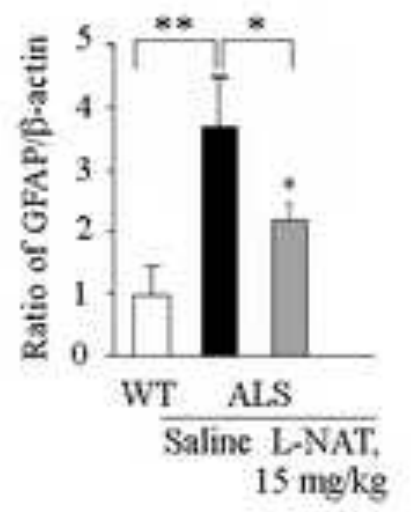

17-18 weeks

MW

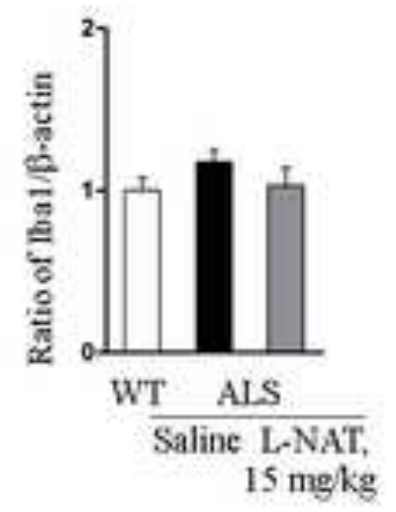

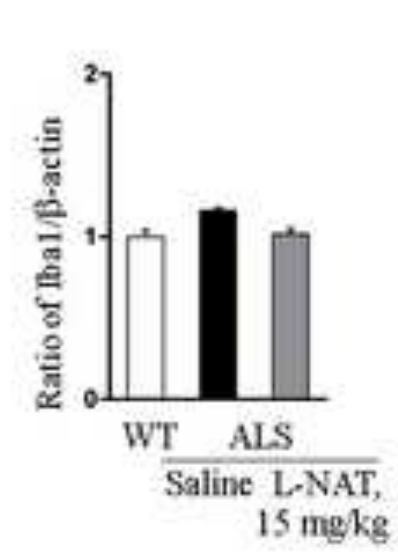

13-14 weeks

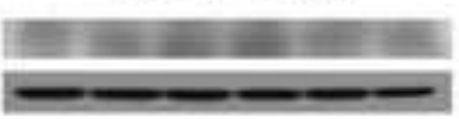

$-\quad++++$
B

17-18 weeks
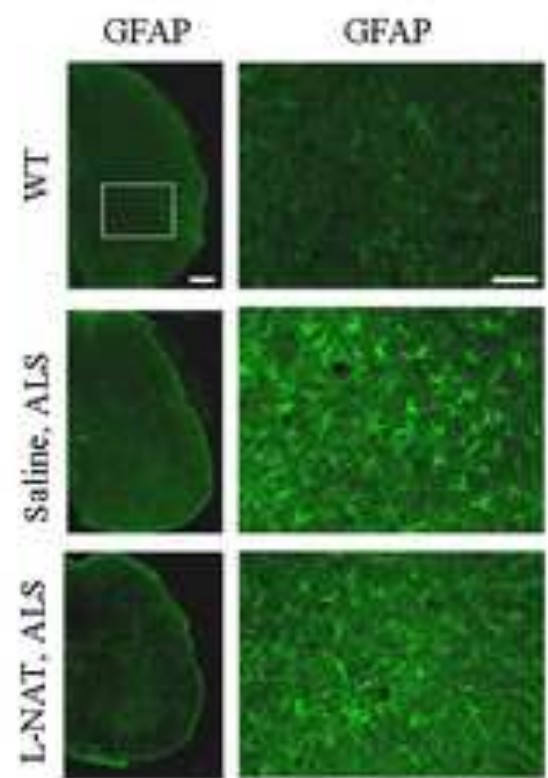

D
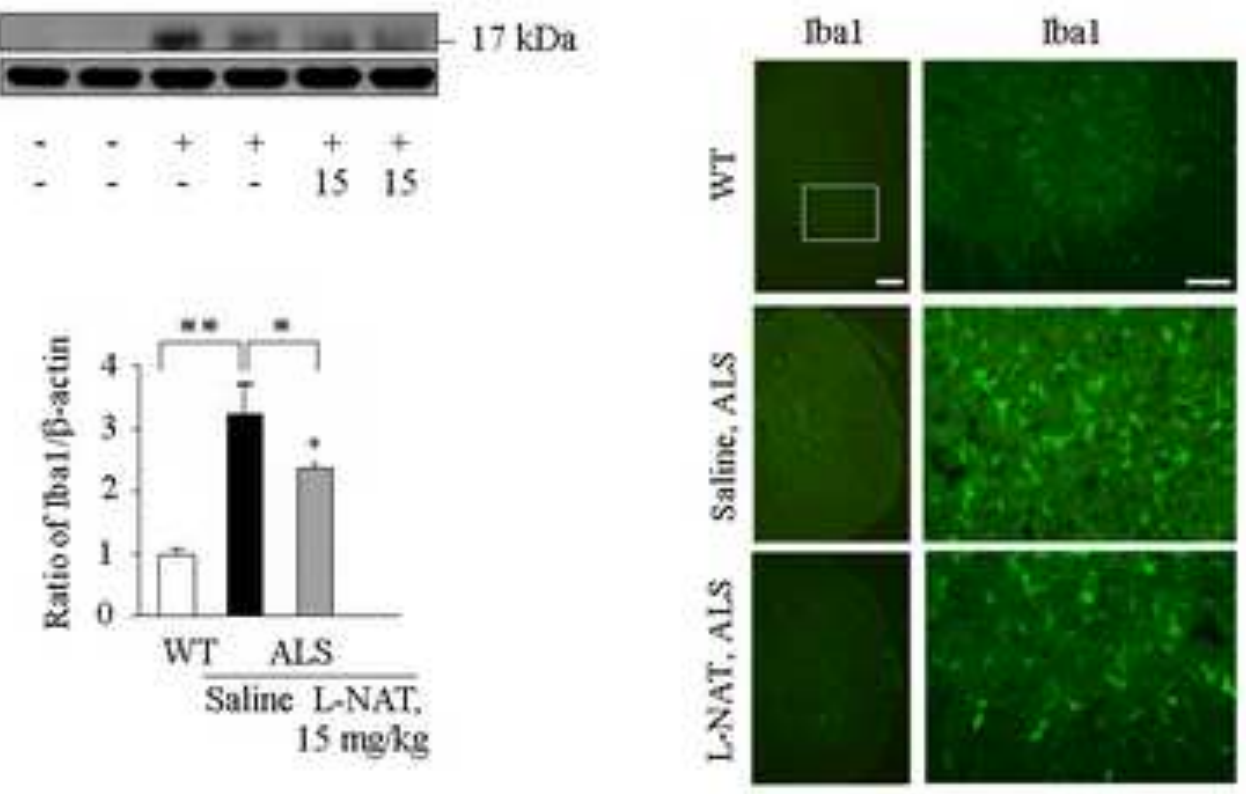
Figure 6 A
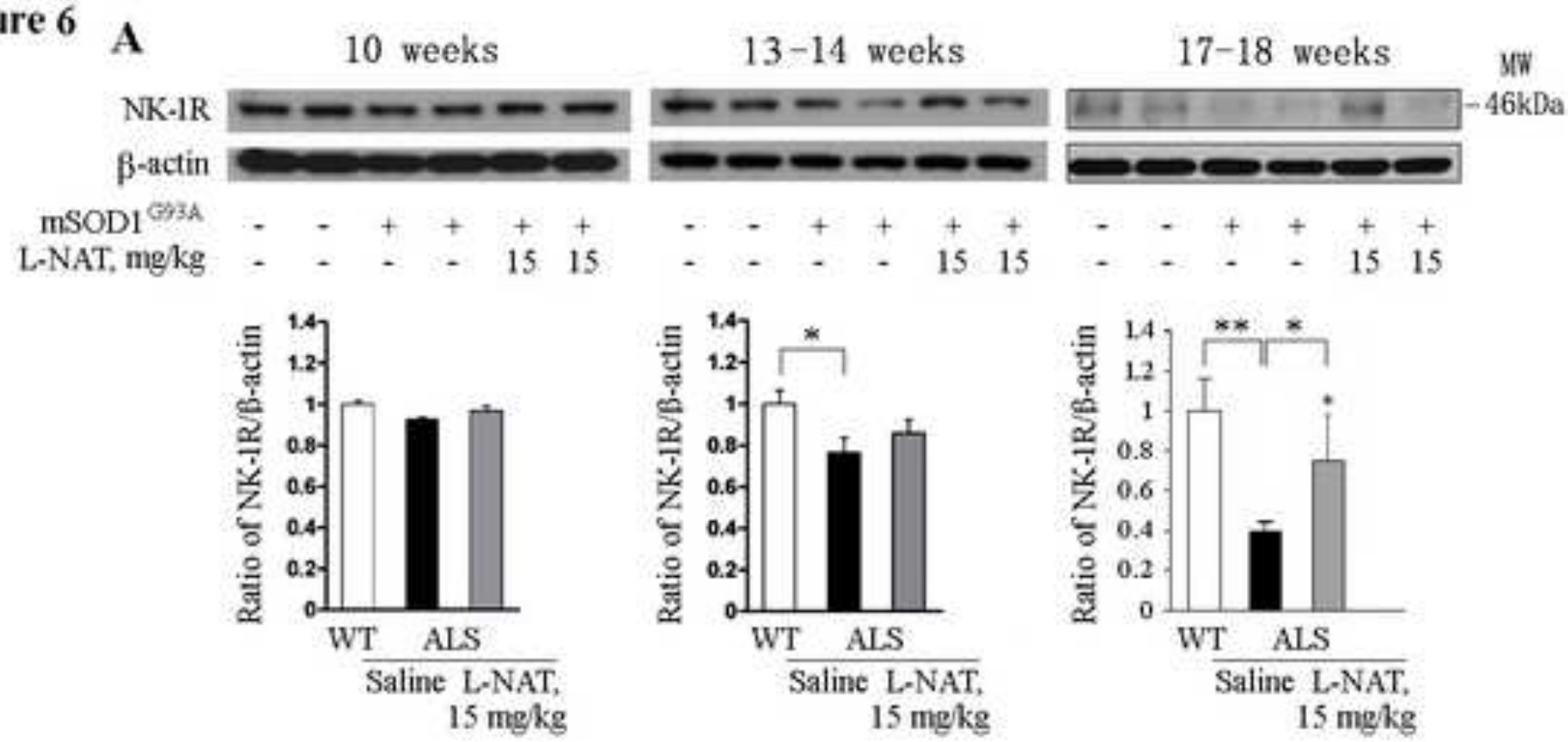

$15 \mathrm{mg} / \mathrm{kg}$
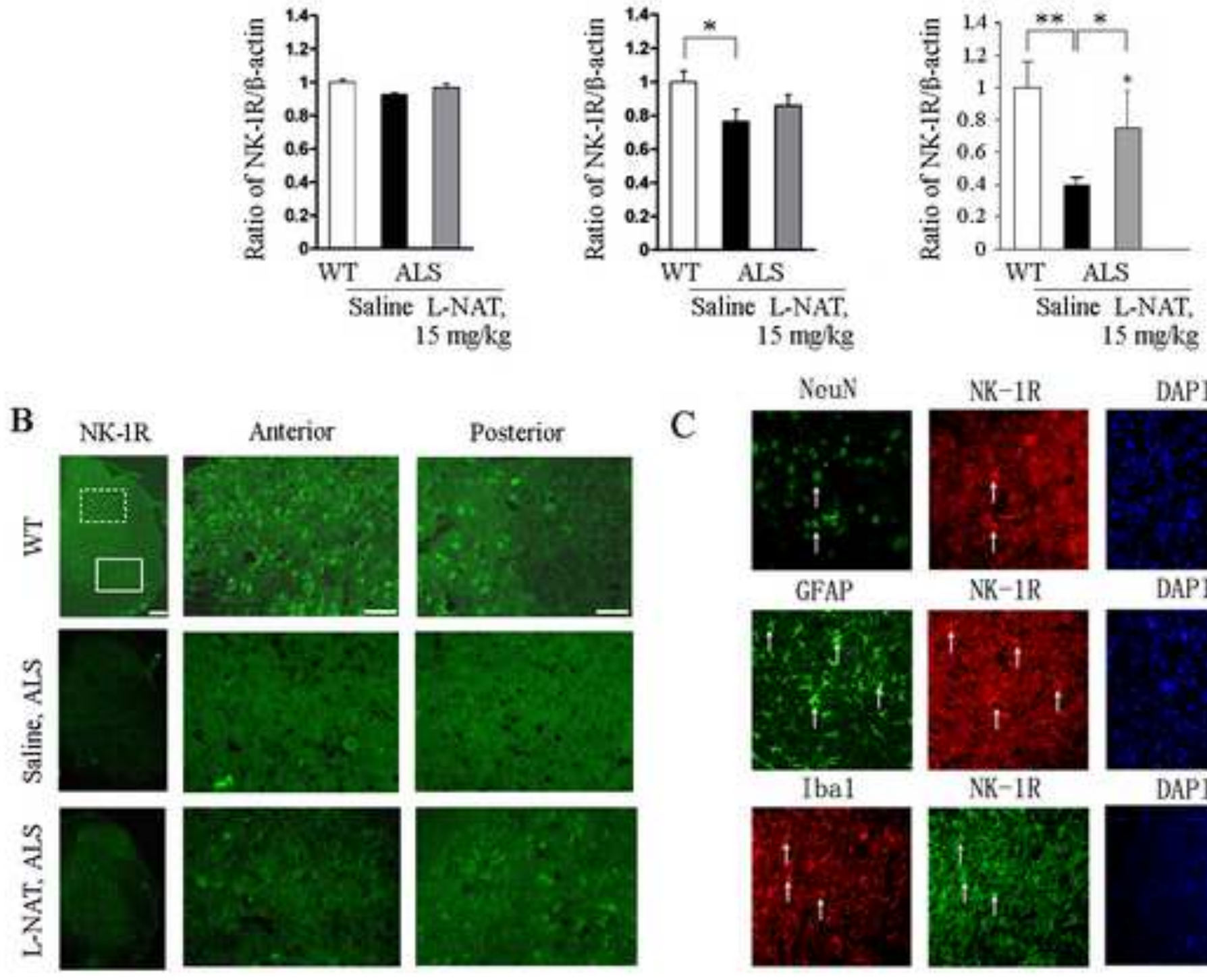

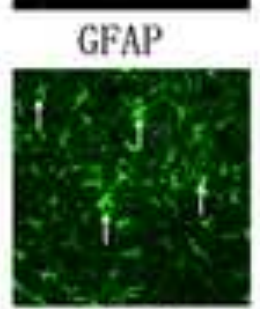

$$
\text { Ibal }
$$

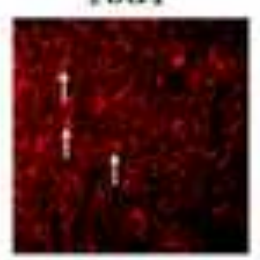

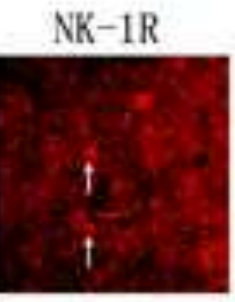

NK-1R

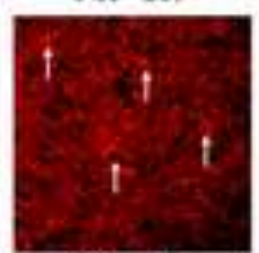

NK-IR

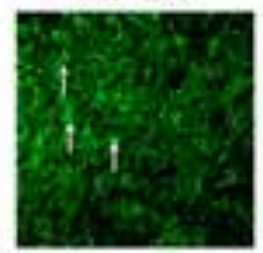

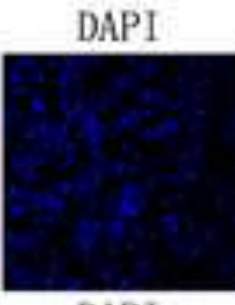

DAPI

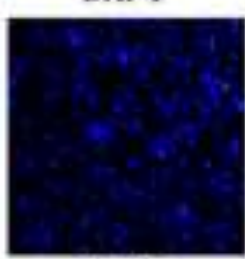

DAPI

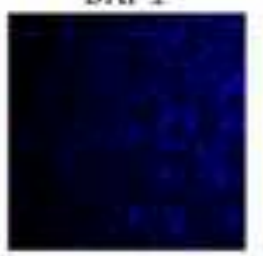

Merge

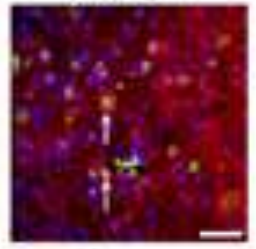

Merge

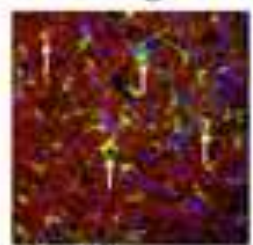

Merge

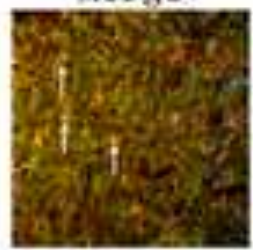

